\title{
SOBRE UN DIBUJO INÉDITO DE LA PLANTA DE LA CATEDRAL DE GRANADA EN 1594
}

\author{
POR \\ DELFÍN RODRÍGUEZ RUIZ \\ Universidad Complutense
}

The finding of the ground plan of the Cathedral of Granada, the only ground plan known of the 16th and 17th centuries, gives origin to this study of one of the most passionate buildings of European Renaissance architecture. Its historic as well as historiographic importance is fundamental, since the drawing traced by Juan de la Vega is a witness of what construction was to be considered up until 1594, the year of its realization; an interpretation of what was originally projected by Diego de Siloe and at the same time an anticipation of solutions that were to be offered in later years.

A Elena Santiago Páez, que me contagió su pasión por la fragilidad de los dibujos.

Es frecuente, lamentablemente, que de muchos de los más importantes edificios de la arquitectura española no se conserven dibujos o tan sólo una mínima parte de los que, sin duda, debió generar su construcción, sobre todo cuando ésta fue larga en el tiempo. El caso de la catedral de Granada, posiblemente uno de los más impresionantes y apasionantes edificios de nuestro Renacimiento, es, en ese sentido, paradigmático. Desde el proyecto gótico originario de Enrique Egas, rápidamente abandonado por el decisivo y «a la romana» de Diego de Siloe, maestro mayor de la catedral entre 1528 y 1563, al que hay que sumar las alteraciones y cambios que pudieron introducir sus continuadores en la maestría mayor, los dibujos producidos fueron sin duda numerosos, según es posible deducir de la documentación conocida ${ }^{1}$. No sólo se han

\footnotetext{
${ }^{1}$ La bibliografía sobre la catedral de Granada es no sólo numerosa, sino también importante para el análisis historiográfico y crítico de la arquitectura del Renacimiento en España. Además de la fundamental e imprescindible obra de E. E. Rosenthal, La catedral de Granada. Un estudio sobre el Renacimiento español, Granada, 1990 (ed. inglesa, Princeton, 1961), hay que mencionar los estudios previos de M. Gómez Moreno González, Guía de Granada, Granada, 1892 (Cito por la ed. facsímil, Granada, 1994, págs. 254 y ss.) y de M. Gómez-Moreno Martínez, Las Aguilas del Renacimiento español, (1. a ed., Madrid, 1941), Madrid, 1983 e Id., Diego Siloe, Granada, 1963. Del propio Rosenthal véase también Diego de Siloe, arquitecto de la Catedral de Granada, Granada, 1966. Entre los abundantes estudios sobre la catedral granadina véanse A. Gallego Burín, Granada. Guía artística e histórica de la ciudad, Granada, 9. a ed., 1993, págs. 254 y ss.; V. Nieto Alcaide, Las vidrieras de la Catedral de Granada, Granada, 1973 y J. M. Pita Andrade, Capilla Real y Catedral de Granada, León, 1978. Además de los análisis contenidos en algunas obras generales sobre la arquitectura española del siglo XVI, entre las que hay que mencionar las de V. Lampérez y Romea, Historia de la Arquitectura Cristiana Española, Madrid, 1930; F. Chueca Goitia, Arquitectura del siglo XVI, vol. XI de Ars Hispaniae, Madrid, 1953; V. Nieto Alcaide,
} 
constatado pagos a Egas por sus dibujos, sino, sobre todo a Siloe, tanto por los realizados para el proyecto y los parciales de obra, según iba creciendo la catedral, como por los que hizo para la construcción de la maqueta por la que habría de seguirse el proceso del proyecto, todos ellos documentados por Rosenthal.

Aunque lamentablemente ninguno de esos dibujos, ni los que necesariamente debieron realizar los aparejadores de Siloe, se conserva, su estudio a partir de la descripción escrita de los mismos podría permitir un apasionante trabajo sobre los métodos y sistemas de representación manejados por nuestros arquitectos del Renacimiento. Es más, la maqueta de la catedral debió ser magnífica y sobradamente detallada sỉ hemos de atender a su largo proceso de realización, casi cuatro años (1528-1532), y al relativamente elevado número de artesanos que trabajaron en ella, casi todos de origen francés, entre los que se encontraban Pierre Guillebert y Foursy Mar$\operatorname{loy}^{2}$. Un origen, una presencia y una influencia como la francesa que no debe desdeñarse a la hora de estudiar la arquitectura andaluza del Renacimiento, casi siempre analizada en relaciôn a los modelos italianos, y que afectó tanto a los repertorios ornamentales como a la esteréometría, como he tenido oportunidad de estudiar en otro lugar ${ }^{3}$.

Se trata de dibujos y de una maqueta que permiten explicar el riguroso proceso de control del proyecto usado por Siloe en la construcción de la catedral de Granada, siguiendo, sin duda, principios albertianos en la consideración disciplinar y ética del dibujo y del modelo ${ }^{4}$. Un proceso del proyecto atento a los nuevos sistemas de representación de la arquitectura, que ya fueron codificados por la cultura italiana desde Alberti y especialmente por Rafael en su célebre Carta a León $X$, y que constituyen un instrumento íntimamente unido a la construcción del clasicismo, a la construcción de una arquitectura «a lo romano» como era denominada en España.

Por otra parte, los dibujos que generó la obra de la catedral de Granada permiten descubrir otras funciones y usos del dibujo de arquitectura diferentes de las convencionales. Es más, la

A. Morales y F. Checa, Arquitectura del Renacimiento en España, Madrid, 1989 y F. Marías, El largo siglo XVI, Madrid, 1989, son importantes los recientes estudios sobre aspectos concretos de la arquitectura de la Catedral contenidos en F. Marías y A. Bustamante, «La catedral de Granada y la introducción de la cúpula en la España del Renacimiento», en Boletín del Museo e Instituto Camón Aznar, núm. VIII, 1982, págs. 103-115; F. Marías, «De iglesia a templo: notas sobre la arquitectura religiosa del siglo XVI», en E. E. Rosenthal et alt., Arquitectura Imperial, Granada, 1988, págs. 113-135; P. A. Galera Andreu, «La cabecera de la Catedral de Granada y la imagen del «Templo de Jerusalén», en Cuadernos de Arte, Universidad de Granada, núm. XXIII, 1992, págs. 197-117, la polémica y brillante interpretación contenida en M. Tafuri, «Il palazzo di Carlo V a Granada: architettura «a lo romano» e iconografia imperiale», en Ricerche di Storia dell'arte, núm. 32, 1987, págs. 4-26, con posteriores precisiones sobre el edificio de la catedral contenidas en su revisión del artículo mencionado en «La Granada di Carlo V: il palazzo, il mausoleo», en M. Tafuri, Ricerca del Rinascimento. Principi, città, architetti, Turín, 1992, págs. 255-304 y las noticias de archivo contenidas en J. M. Gómez-Moreno Calera, La arquitectura religiosa granadina en la crisis del Renacimiento (1560-1650), Granada, 1989, págs. 125 y ss.

2 Siloe no sólo realizó los dibujos para el proyecto, sino que, además, hizo otros expresamente para la maqueta, ilustrando así las diferentes ideas que sobre la representación de la arquitectura y sus funciones pơdían manejar los arquitectos del Renacimiento en España. Sobre la maqueta de la catedral de Granada y los dibujos de Siloe véase E. E. Rosenthal, La catedral de Granada, op. cit., págs. 29-30 y Documentos 53, 54 y 55. La bibliografía sobre maquetas ha conocido en los últimos años un notable crecimiento, así como el interés por conservar ese particular y frágil patrimonio. Véanse al respecto, por sólo citar algunos títulos, M. Scolari, «L'idea de modello», en Eidos, núm. 2, 1988, págs. 16-39; el número monográfico sobre «Maquette» de la revista Rasegna, num. 32, 1987, o el reciente H. A. Millon, «I modelli architettonici nel Rinascimento», en H. A. Millon y V. Magnago Lampugnani (eds.), Rinascimento. Da Brunelleschi a Michelangelo. La rapressentazione dell'architettura, Milán, 1994. En España aún falta un inventario y, en consecuencia, estudios sobre las maquetas conservadas, aunque existan algunas excepciones.

${ }^{3}$ D. Rodríguez Ruiz, «Un álbum de dibujos inédito de Androuet Du Cerceau: modelos franceses en la arquitectura andaluza del Renacimiento», en Revue de l'art (en prensa).

${ }^{4}$ Véase, al respecto, imprescindible estudio de E. Battisti, «El método proyectual según el "De Re Aedificatoria" de Leon Battista Alberti», en E. Battisti, En lugares de vanguardia antigua. De Brunelleschi a Tiépolo, Madrid, 1993, págs. 43-84. 
construcción del edificio no siempre se guió por la maqueta y las trazas originales de Siloe o de su aparejador y sucesor Juan de Maeda, sobre todo a partir de la muerte de este último en 1576, cuya sucesión, por otro lado, dio origen a un apasionante concurso restringido entre arquitectos en el que las directrices fueron marcadas por el hijo de aquél, Asensio de Maeda, heredero, además, de los dibujos de Siloe y de su padre, entre los que habrían de encontrarse no pocos relativos a la catedral de Granada.

El concurso propuesto por Asensio de Maeda en 1576 y aprobado por el Cabildo de la Catedral, documentado y estudiado por Rosenthal, consistió en un debate entre arquitectos, cuyos nombres fueron decididos por el propio Maeda. Los concursantes debían presentar un proyecto de terminación del edificio, que afectaba sustancialmente a las naves, la fachada principal, el sagrario y el claustro. Proyecto sobre el que, sin duda, debió pesar el original de Siloe (los dibujos y la maqueta), aunque los arquitectos introdujeran variantes y modificaciones significativas. El proyecto debía ir representado en tres dibujos, con la planta, el alzado de la fachada y una sección, aunque a la postre presentaron muchos más ${ }^{5}$.

Por otra parte, Lázaro de Velasco, traductor de Vitruvio ${ }^{6}$, pintor de libros miniados ${ }^{7}$ en la Catedral de Granada y uno de los arquitectos propuestos por Asensio de Maeda, planteó el 15 de abril de 1577 que los arquitectos que iban a participar en el concurso, para ofrecer otra prueba de su capacidad y habilidad, deberían presentar además un proyecto de «un templo de yglesia cathedral de tres naves o cinco naves con hornezinas o sin ellas con cruzero, zimborio, altar mayor, trascoro que difiera desta hecha y tenga lo que tiene ésta y más que esta y no tanto como ésta y vaya quasi al modo de ésta y sea una novedad que no se haya hecho y tenga bizarría» ${ }^{8}$. Los dibujos debían, según el mismo Lázaro de Velasco, ser realizados renunciando a la seducción del comitente, atentos exclusivamente a la capacidad constructiva del arquitecto, a su dominio de las reglas ya que «no está el negocio de la opposición en hazer los designos y muestras con debuxicos muy peleteados plumeados relamidicos con aguadas acabadicas ni en hazer un capitelico con mucha patientia ni en debuxos ni en figuras ni pinturas Románicas sino quien ordena con más fundamento para cantería de piedra y lo traça y da a entender y explica y demuestra con prudente entendimiento que no nos llaman a pintar sino a abraçar y juntar piedras con mezcla en un sumptuoso visto y perpetuo edifiçio».

Las afirmaciones de Velasco atribuyen a los dibujos de los arquitectos españoles unas carecterísticas sorprendentes. Las mismas que, por otra parte, rechaza en favor de un diseño disciplinar y no de «pintor». Afirmaciones que no pueden dejar de sorprender si tenemos presentes los dibujos conservados de nuestros arquitectos del siglo XVI y, a la vez, resultan muy reveladoras de lo que parece que se ha perdido. Sea como fuere, sus indicaciones sobre la presentación de ese segundo proyecto ideal, no destinado a la construcción, sino a medir la habilidad y conocimiento de las reglas de la arquitectura, fueron aceptadas por el Cabildo de la Catedral. De este modo, los arquitectos que participaron en el concurso de 1577, Francisco del Castillo, Juan

${ }^{5}$ El elevado número de dibujos, casi cincuenta «pliegos», que presentaron los arquitectos participantes en el concurso de 1577 aparece documentado el 17 de mayo de aquél año. Véase E. E. Rosenthal, La catedral de Granada, op. cit., doc. 148, pág. 224. Desgraciadamente ninguno de ellos se conserva, como tampoco los anteriores de Egas, Siloe o Maeda.

${ }^{6}$ Sobre la traducción manuscrita del tratado de Vitruvio realizada por L. de Velasco en Granada entre 1554 y 1564, véase F. Marías y A. Bustamante, «El Escorial y la cultura arquitectónica de su tiempo», en E. Santiago Páez (ed.), El Escorial en la Biblioteca Nacional, Madrid, 1985, págs. 194-198. Sobre el uso y recepción de Vitruvio he tratado en D. Rodríguez Ruiz, «Diez libros de Arquitectura: Vitruvio y la piel del clasicismo», introducción a Vitruvio, Los diez libros de arquitectura, Madrid, 1995, págs. 11-51.

7 M. A. Álvarez Castillo, «Lázaro de Velasco, pintor de libros de coro en la Catedral de Granada», en Cuadernos de Arte, Universidad de Granada, núm. XXIII, 1992, págs. 119-125.

${ }^{8}$ El documento puede verse en E. E. Rosenthal, La catedral de Granada, op. cit., págs. 222-223. 
de Orea y el propio Lázaro de Velasco, debieron presentar ambos proyectos y además defenderlos teóricamente, así como criticar los realizados por los otros participantes. Un debate que afortunadamente conservamos y que resulta fundamental para conocer la cultura arquitectónica en la España del Renacimiento ${ }^{9}$.

De esta segunda serie de dibujos tampoco parece conservarse ninguno, a no ser que pudiera relacionarse con alguno de los proyectos de catedral ideal presentados por los arquitectos mencionados la sección sobre pergamino que, atribuida a un anónimo arquitecto andaluz, conserva la Biblioteca Nacional (B 104) ${ }^{10}$. Por otra parte, Rosenthal supuso que el dibujo de la Catedral de Granada que mencionan Llaguno en sus Noticias ${ }^{11}$ y Gómez-Moreno en su Guía de Granada ${ }^{12}$, conservado en el archivo de la Abadía del Sacromonte, y hoy perdido, pudiera corresponder al proyecto de Lázaro de Velasco para la terminación del edificio granadino. Se trataría de un dibujo que tanto Llaguno como Gómez-Moreno atribuyeron a Siloe, basándose el primero muy verosímilmente en las noticias contenidas al respecto en la todavía útil y erudita obra de Juan Velázquez de Echeverría, Paseos por Granada y sus contornos, publicada en $1764^{13}$. El párrafo que me interesa destacar de los Paseos, escritos en forma de diálogo entre un Granadino, el propio Velázquez, y un Forastero, dice lo siguiente: «Gran. En un gran pergamino he visto la planta, que se hizo para ella. Está guardado en el Archivo de la Colegial del Sacro-Monte. Fue hecha esta planta por el Insigne Diego Siloe, peritissimo Arquitecto», y más adelante se puede leer: «Si estuvieran las dos Torres, que segun la planta debia tener la Iglesia, acabadas, seria incomparable la hermosura» ${ }^{14}$.

En definitiva, de los numerosos dibujos que sobre la catedral de Granada se hicieron en el siglo XVI no se han conservado prácticamente ninguno, $\mathrm{o}$, al menos, no se han localizado los que debieron guardarse en el archivo de la catedral o en la Abadía del Sacromonte, ni los que reunió Asensio de Maeda. De finales del siglo XVI y comienzos del XVII, una época en la que se avanzó poco en la construcción de la catedral, se conservan, sin embargo, tres representaciones del edificio, atribuidas a quien fuera su maestro mayor durante muchos años, Ambrosio de Vico ${ }^{15}$,

${ }^{9}$ E. E. Rosenthal, La catedral de Granada, op. cit., págs. 219 y ss. Véase también A. Moreno Mendoza, Francisco del Castillo y la arquitectura manierista andaluza, Jaén, 1984.

${ }^{10}$ F. Marías y A. Bustamante han estudiado el dibujo mencionado, señalando que aunque cabría la posibilidad de vincular el lenguaje arquitectónico empleado con las características de alguno de los arquitectos que presentaron proyectos ideales en el concurso granadino de 1577 , de las actas del mismo parece desprenderse «que no hay dato alguno que nos permita vincular este diseño a cualquiera de los proyectos de estos maestros», en F. Marías y A. Bustamante, «Anónimo andaluz del siglo XVI, Catedral, sección longitudinal (B 104)», núm. 5 del catálogo AA. VV., Dibujos de Arquitectura y Ornamentación de la Biblioteca Nacional. Siglos XVI y XVII, Tomo I, Madrid, 1991, pág. 10.

${ }^{11}$ E. Llaguno, Noticias de los arquitectos y arquitectura de España desde su Restauración, Madrid, 1829, vol. I, pág. 199.

12 M. Gómez-Moreno, Guía de Granada, op. cit., pág. 262.

${ }_{13}$ Cito por la edición facsímil de la de 1764 publicada en Granada, 1993, 2 vols., con estudio introductorio de C. Viñes Millet.

14 J. Velázquez de Echeverría, Paseos por Granada, op. cit., págs. 303 y 308. Velázquez de Echeverría se refiere a un dibujo que representa la planta de la Catedral de Granada, mientras que Llaguno es más impreciso, señalando que se trata de un diseño, y Gómez-Moreno, por su parte, parece describir un alzado, que Rosenthal identifica con el propuesto por Lázaro de Velasco para la fachada de la catedral de Granada. Se trate de tres dibujos distintos, o del mismo, dibujo, lo cierto es que todos coinciden en señalar que se conservaba en la Abadía del Sacromonte, cuyo archivo y biblioteca se encuentran hoy muy mermados con respecto a los fondos que poseía durante los siglos XVIII y XIX. Rosenthal (La catedral de Granada, op. cit., pág. 56) también señaló que era posible que el dibujo que menciona Llaguno fuera alguna copia de las que se hicieron en 1664 de los planos del siglo Xvi. Según el historiador norteamericano, Llaguno lo habría visto, aunque conociendo cómo elaboró nuestro ilustrado sus Noticias cabe pensar en una referencia de segunda mano como ya he indicado.

${ }^{15}$ La vinculación de A. de Vico a la catedral de Granada comienza en 1575, siendo maestro mayor de la misma entre 1588 y 1623, casi cincuenta años en los que, sin embargo, la construcción apenas avanzó. Sobre el arquitecto véase la monografía de J. M. Gómez-Moreno Calera, El arquitecto granadino Ambrosio de Vico, Granada, 1992. Un dibujo inédito 
coincidiendo, entre otros, con el arzobispado de Don Pedro de Castro (1590-1610), figura decisiva en la historia religiosa y cultural granadina.

De A. de Vico, experimentado constructor, aunque mediocre dibujante, a pesar de los beneméritos esfuerzos realizados por su más reciente biógrafo por presentarlo como un esmerado diseñador ${ }^{16}$, se conservan tres dibujos relativos a la catedral de Granada. El primero de ellos, autógrafo, es una planta de la torre comenzada a elevar en la fachada y que en 1590 presentó serios riesgos sobre su seguridad, procediéndose a su restauración y nueva cimentación (Fig. 14). Conservado en el Archivo de Simancas, es un dibujo de obra interesante tanto desde un punto de vista constructivo como social por la polémica que levantó su posible ruina ${ }^{17}$. Los otros dos dibujos fueron preparados, si ambos pueden atribuirse a Vico, para ser grabados e ilustrar la obra de Justino Antolínez de Burgos, Historia Eclesiástica de Granada (ca. 1620), que a la postre quedaría manuscrita y fue escrita bajo los auspicios del arzobispo Don Pedro de Castro. Una de las estampas representa una sección transversal en proyección ortogonal de la capilla mayor de la catedral y la otra es la célebre Plataforma de la ciudad de Granada, ambas grabadas por Francisco Heylán (ca. 1584-ca. 1650) ${ }^{18}$ hacia 1613-1614. En la primera estampa, no figura el autor del dibujo, aunque desde M. Gómez-Moreno se le viene atribuyendo, mientras que el nombre de Vico sí aparece en la Plataforma ${ }^{19}$.

Se trata de dos dibujos que no tienen fines proyectuales, sino que representan lo construido y constituyen un precioso testimonio del estado de las obras de la catedral a finales del siglo XVI y comienzos del siguiente. La Plataforma (Fig. 11) presenta una vista en perspectiva caballera, en proyeccción oblicua, de la ciudad de Granada, con una información detallada de calles y edificios, constituyendo un documento inestimable de información urbana, si bien el sistema de representación utilizado no parece controlado con suficiencia por Vico, llegando a alterar, posiblemente también con fines simbólicos, la disposición de algunas construcciones en el entramado de la representación, como ocurre, por ejemplo, con el palacio de Carlos V, que aparece aislado y cambiado de posición con respecto al palacio nazarí de la Alhambra. Pero lo que ahora más me interesa de la Plataforma es la representación de la catedral, Capilla Real y antigua mezquita (como sagrario e iglesia vieja es descrita y usada en la época), tal como estaban en ese momento, con la capilla mayor construida, levantada la pared norte de las naves hasta la torre, así como señalados en planta los cimientos de los pilares y de la fachada.

Este fragmento de la Plataforma es, en realidad, el único testimonio gráfico que poseíamos del proceso constructivo derivado del proyecto completo de Siloe, si exceptuamos algunas vistas generales de la ciudad dibujadas en los años sesenta del siglo XVI, como después podrá verse. Aún así, lo escueto e impreciso del diseño de Vico sólo permite valorarlo en función de su carácter informativo global, especialmente en lo relativo a la paralización de las obras durante un largo período de tiempo. Sin embargo, la otra estampa señalada (Fig. 8), que ilustra la sección de la capilla mayor, es un dibujo perfectamente controlado desde el punto de vista de la represen-

de Vico para la cripta de San Jerónimo el Real de Granada puede verse en A. Bustamante García, «El sepulcro del Gran Capitán», en Boletín del Museo e Instituto «Camón Aznar», LXII, 1995, págs. 5-42.

16 J. M. Gómez-Moreno Calera, El arquitecto granadino Ambrosio de Vico, op. cit., págs. 143 y ss.

17 Véase, al respecto, F. J. Gallego Roca, «Documentos relativos a la torre de la Catedral de Granada», en Cuadernos de Arte, Universidad de Granada, núm. 17, 1985-86, págs. 11-130.

${ }_{18}$ Sobre Heylán y las estampas mencionadas, véase Moreno Garrido, A., «El grabado en Granada durante el siglo XVII. I: La Calcografía», número monográfico de Cuadernos de Arte, Universidad de Granada, 1976, especialmente las págs. 94-97.

19 Sobre estos problemas de atribuciones y fechas de ejecución de los grabados y dibujos, véase J. M. Gómez-Moreno Calera, El arquitecto granadino Ambrosio de Vico, op. cit., págs. 149 y ss. En concreto, sobre la Plataforma de Granada, véase Moreno Garrido, A., Gómez-Moreno Calera, J. M. y López Guzmán, R., «La Plataforma de Ambrosio de Vico: cronología y gestación», en Arquitectura Andalucía Oriental, núm. 2, 1984, págs. 6-11. 
tación en proyección ortogonal. Un dibujo, de nuevo, no proyectual, sino levantamiento de lo existente o copia de un dibujo anterior que incluye además el viejo tabernáculo de Siloe, sustituido en 1614. La calidad y rigor del diseño parece ajena a la de los dibujos que conocemos de Vico, aunque resulte difícil mencionar un nombre de autor distinto de quien ostentaba la maestría mayor de la catedral en aquellos años, si es que no está basado en un dibujo de previo. Se trata de una imagen que, en cualquier caso, representa el estado de la capilla en las fechas en las que fue grabada.

No termina el siglo XVI, a pesar de todo, sin imágenes que representen la catedral de Granada, si bien es cierto que de las decenas de dibujos que acompañaron proyectualmente su construcción durante esa centuria, en la que los príncipes (Carlos V, Felipe II y los correspondientes arzobispos) parecían ser los ojos y los arquitectos las manos ejecutoras ${ }^{20}$, sólo era conocida, hasta ahora, la planta de la torre dibujada por Vico y ya mencionada. Recientemente, sin embargo, Galera Andreu llamaba la atención sobre otras representaciones de la catedral, tradicionalmente no consideradas suficientemente por los historiadores del edificio en sus estudios sobre el proyecto, construcción y significado de la catedral de Granada ${ }^{21}$. Me refiero a las vistas exteriores del volumen del edificio, cuya representación más conocida es la imagen de la rotonda de la capilla mayor atribuida a Velázquez (Fig. 6) y conservada en la Biblioteca Nacional, aunque con anterioridad la rotonda de la catedral ya ocupó un lugar importante en la definición iconográfica y simbólica del edificio y de la ciudad, como puede comprobarse en las vistas de Joris Hoefnagel grabadas en la fundamental obra de Georg Braun y Frans Hogenberg, Civitates Orbis Terrarum, publicada en seis volúmenes en Colonia, entre 1572 y 1617 (Figs. 4 y 5). Las tres vistas de Granada dibujadas por Hoefnagel pueden fecharse en 1563 y 1564, durante su viaje por España, y son contemporáneas de la que realizara en 1567 Anton van den Wyngaerde ${ }^{22}$ (Fig. 3), es decir, poco después de la muerte de Siloe. Vistas exteriores de la catedral que acentúan su carácter monumental y emblemático en la trama urbana, así como exaltan la atención que a su perfil y volumen figurativo había concedido el propio Siloe y que ya fue agudamente entendido por uno de los concursantes en el debate de 1577 organizado para elegir al nuevo maestro mayor de la construcción. De este modo, Lázaro de Velasco podía defender su proyecto en los siguientes términos: «Quanto a lo primero se a de considerar que el espacio que oviere de tomar la torre se le tiene de dexar de la misma forma y grandeza de la compañera, que agora se va prosiguiendo, porque aunque es verdad que la vista no pueda comprehender la una torre y la otra, para juzgar si alguna de ellas es mayor o menor por no tener el templo distancia de plaça para poderlo juzgar con la vista, quando vengan a predominar por encima de toda la ciudad, se juzgará dende el campo y será imperfection y fealdad y contra los preceptos de arquitectura» ${ }^{23}$. Es decir, que los arquitectos ya tuvieron presente, desde el siglo XVI, una doble per-

\footnotetext{
${ }^{20}$ Sobre esa función subsidiaria del arquitecto frente a las decisiones del príncipe, ojo intelectual de la arquitectura véase M. Scolari, «L'idea de modello», op. cit, págs. 25 y ss., y D. Rodríguez Ruiz, «¿Aún es posible hacer historia de la arquitectura?», en Anales de Historia del Arte, Universidad Complutense de Madrid, núm. 6, 1996, págs. 333-339.

${ }^{21} \mathrm{Al}$ respecto de los análisis sobre la catedral de Granada, observa Galera Andreu: «cuanto se ha escrito se basa en una mirada fundamentalmente "hacia adentro", a la valoración del espacio interior, de su articulación y de su ornato; mientras que si apenas se ha meditado sobre su imagen externa, quizá por presentarse la Rotonda, desde un punto de vista arquitectónico, contradictoria con su pesada configuración externa, teñida de medievalismo». La aguda consecuencia de la atención a lo exterior del edificio ha llevado al autor a proponer una interpretación de la catedral como nuevo Templo de Jerusalén, significado que habría que añadir a las interpretaciones simbólicas propuestas por Rosenthal, F. Marías y M. Tafuri en sus estudios citados, ya sea como sepulcro y capilla imperial o reconstrucción simbólica del Santo Sepulcro de Jerusalén o del Panteón de Roma. Véase P. Galera Andreu, «La cabecera de la Catedral de Granada...», op. cit. págs. 108 y ss.

${ }^{22}$ Sobre las vistas de Wyngaerde véase R. Kagan (ed.), Ciudades del Siglo de Oro. Las vistas españolas de Anton van den Wyngaerde, Madrid, 1986.

${ }^{23}$ Cit. en Rosenthal, La catedral de Granada, op. cit., doc. 150A, págs. 224-225.
} 
cepción del edificio. La primera, interior, atenta al rito y la liturgia, a lo simbólico, a los lenguajes arquitectónicos y a la tipología. La segunda, la exterior, emblema de la misma ciudad de Granada, pensada para ser vista de lejos, en su perfil urbano: una arquitectura que, junto con los palacios nazarí y de Carlos V en la Alhambra, configuran la imagen simbólica y política de la ciudad. Algo que aún estaba presente en las consideraciones que Echeverría podía enunciar en sus Paseos al hablar sobre la catedral, señalando que «conspira todo à cerrar en media Naranja el Edificio, con una valentìa inimitable, tanto en lo interior, como en lo exterior. Pues si V. la registra por fuera le llevarà la vista, la grande Mole, y la delicadeza con que en una corpulencia tan vasta se hacen admirar todas sus partes.» ${ }^{24} \mathrm{Y}$ se trata de una valoración específicamente arquitectónica, entendiendo el edificio como forma y lenguaje de la maravilla, sólo comparable (y no es la primera vez que aparecía semejante parangón) a Santa Sofía de Constantinopla ${ }^{25}$. Una comparación que podría abrir ulteriores significados añadidos por la historia a los conocidos y mencionados con anterioridad y que ya fue formulada por Bermúdez de Pedraza a comienzos del siglo XVII ${ }^{26}$.

En este contexto, brevemente presentado, adquiere una especial importancia la localización de un dibujo con la representación de la planta de la catedral de Granada. Se trata de la única planta conocida y conservada de los siglos XVI y XVII, al menos mientras no aparezcan otros dibujos. Es obra de Juan de la Vega (Fig. 1) (activo entre 1576 y la fecha de su muerte en 1612), cantero, maestro de obras y aparejador en la Alhambra y en la ciudad y reino de Granada, siendo consultado en diferentes ocasiones sobre las obras de la catedral, especialmente durante la maestría mayor de Ambrosio de Vico, así como también intervino en el palacio de Carlos V, en Santa María de la Alhambra y en otra catedral siloesca como la de Guadix ${ }^{27}$, de la que fue maestro mayor entre 1597 y 1605.

Aparejador poco considerado por los historiadores de la arquitectura granadina, lo cierto es que tuvo la oportunidad de construir, tasar, medir y proyectar en las más importantes construcciones de Granada, incluida la catedral. Vega, durante la maestría de Vico (1582-1623) intervino en diferentes momentos, sobre todo a partir de 1583 y también con motivo de la destrucción, en 1588, de la llamada Torre Turpiana ${ }^{28}$ (Fig. 9), antiguo alminar de la mezquita situado en el espacio que habrían de ocupar las naves de la catedral. Fue asímismo consultado para la construcción del crucero y coro, así como en el ya citado proceso de restauración y consolidación de la única de las torres de la fachada que había comenzado a ser levantada en los años anteriores.

Su experiencia y condición de aparejador de la obras reales de la Alhambra hicieron necesaria y habitual su presencia en los pocos momentos en los que se realizaron tareas constructivas de alguna envergadura durante el largo período de inactividad que sufrió la catedral de Granada,

\footnotetext{
24 J. Velázquez de Echeverría, Paseos por Granada..., op. cit., pág. 305.

25 J. Velázquez de Echeverría, Paseos por Granada..., op. cit., pág. 307.

${ }^{26}$ Cit. en M. Gómez-Moreno, Diego Siloe, op. cit., pág. 66.

27 Sobre Juan de la Vega, véanse las referencias contenidas en las obras citadas de los Gómez-Moreno y Gallegon Burín, así como en E. E. Rosenthal, El Palacio de Carlos V en Granada, Madrid, 1988 y J. M. Gómez-Moreno Calera, La arquitectura religiosa granadina..., op. cit.. y las noticias inéditas contenidas en la ya tantas veces citada obra de J. Velázquez de Echeverría, Paseos por Granada, op. cit, pág. 154.

${ }^{28}$ Una imagen de la Torre Turpiana, en el momento de su demolición por peones moriscos, anuncio del descubrimiento de unas reliquias que habrían de dar lugar a toda una fascinante historia de falsificaciones religiosas y culturales, que culminarían con la construcción de la Abadía del Sacromonte, puede verse en una estampa de F. Heylán, grabada, como las otras dos mencionadas relativas a la catedral de Granada, para la ya citada obra de J. Antolínez de Burgos, Historia Eclesiástica de Granada. Sobre la mencionada estampa, véase A. Moreno Garrido, «El grabado en Granada...», op. cit., pág. 91. En relación a las falsificaciones de reliquias y antigüedades granadinas del siglo XVI y de su posterior reanudación en el XVIII véase mi estudio D. Rodríguez Ruiz, La memoria frágil. José de Hermosilla y las Antigüedades Árabes de España, Madrid, 1992, con la bibliografía anterior y también M. J. Hagerty, Los libros plúmbeos del Sacromonte, Madrid, 1980 y J. Caro Baroja, Las falsificaciones de la Historia (en relación con la de España), Madrid, 1991, especialmente las págs. 115-160.
} 
coincidiendo la presencia de A. de Vico y con el arzobispado del citado Pedro de Castro, mucho más preocupado por la construcción de la Abadía del Sacromonte granadino y por las consecuencias que se derivaron de las reliquias encontradas en la demolición de la Torre Turpiana y en el Sacromonte.

El contacto habitual de Juan de la Vega con las obras de la catedral puede explicar la consulta que el arzobispo le hiciera con el fin de resolver un conflicto entre el Cabildo y la Inquisición a propósito de la situación y colocación de los sambenitos en la catedral de Granada, dando motivo a que el aparejador de la Alhambra dibujase la planta que ahora nos ocupa ${ }^{29}$. Aunque resulta un poco extraño que el consultado no fuera Ambrosio de Vico.

No han sido muy frecuentes, por otra parte, los estudios sobre las relaciones entre el arte y la Inquisición en España, más allá del documentado proceso al que fue sometido Esteban Jamete ${ }^{30}$ y de algunos otros breves estudios y datos que se pueden añadir. Sin embargo, recientemente se han realizado dos aproximaciones al problema que aportan conclusiones provisionales diametralmente opuestas sobre la incidencia de la Inquisición en el arte y la arquitectura del siglo $\mathrm{XVI}^{31}$. En cualquier caso, lo cierto es que sería muy interesante encontrar una posición equilibrada y rigurosa sobre las consecuencias de una relación históricamente conflictiva en ámbitos religiosos, sociales, políticos o culturales y, sin duda, artísticos y arquitectónicos. En definitiva, debería indagarse con mayor rigor histórico las relaciones entre arte e Inquisición, buscando un posible equilibrio entre posiciones extremas que parecen dejar sólo hablar a los documentos o a su ausencia. Una ausencia que parece tener como únicos cómplices el silencio y la renuncia del historiador. De este modo, un extremo podría ser el representado por el severo juicio de A. Bustamante García, según el cual, aunque «hubo personas de gusto refinado, que además fueron inquisidores, el Santo Oficio nunca tuvo que ver con el arte, ni para usar de él para sus fines, ni como objeto de sus persecuciones y desvelos. Por eso mismo, ni se ensañó con los artistas, ni fue un comitente de envergadura. Simplemente, a la Inquisición no le interesaba el arte». Otro posible punto de partida, en el extremo opuesto, para estudiar las relaciones entre la Inquisición y el arte, podría ser el representado por un documento escrito por uno de los artistas que dibujaron la catedral Granada. Así, el ya mencionado autor de vistas de Granada, Joris Hoefnagel (Amberes 1542- Viena c. 1600), viajero y dibujante de ciudades por España entre 1563 y 1567, podía, en un libro manuscrito de emblemas dedicados a la Paciencia, fechado en Londres en 1569 y usando de manera consciente e irónica su viaje por la Península, escribir lo siguiente al respecto de uno de ellos relativo a los sambenitos del Santo Oficio: «Meditad sobre mí, cuantos tenéis tratos con las tierras de España. Esto es la Inquisición. El Santo Oficio cuida así de quienes no dominan bien su lengua, persigue a muchos buenos hombres a quienes no les sirve de nada quejarse. Lleva el sambenito. Cierra la boca, cierra la bolsa. Este es el lema del mundo» ${ }^{32}$.

\footnotetext{
${ }^{29}$ Quiero agradecer a los profesores Fernando Bouza y Gregorio de Andrés su ayuda en la localización y estudio del

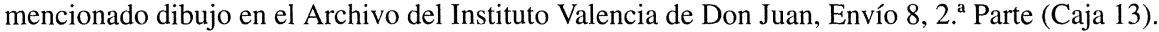

30 Sobre Jamete véanse, entre otros estudios, J. Domínguez Bordona, Proceso inquisitorial contra el escultor Esteban Jamete, Madrid, 1933 y el reciente A. Turcat, Etienne Jamet alias Esteban Jamete. Sculpteur français de la Renaissance en Espagne, condamné par l'Inquisition, París, 1994.

31 Véanse, al respecto, M. Scholz-Hänsel, «La Inquisición como mecenas? Imágenes al servicio de la disciplina y propaganda inquisitorial», en B.S.A.A., LX, 1994, págs. 301-317 y A. Bustamante García, «El Santo Oficio de Valladolid y los artistas», en B.S.A.A., LXI, 1995, págs. 455-466. Son muy interesantes las observaciones de S. Deswarte en «Francisco de Holanda ou le Diable vêtu à l'italienne», en J. Guillaume (ed.), Les Traités d'Architecture de la Renaissance, París, 1988, págs. 327 y ss. Aunque los estudios sobre la Inquisición son muy numerosos, véase el reciente F. Bethencourt, História das Inquisiçoes. Portugal, Espanha e Italia, Lisboa, 1996, con la bibliografía anterior y un muy rico aparato iconográfico y arquitectónico.

${ }^{32}$ El texto se encuentra en J. Hoefnagel, Patientia. Ne Sutor Ultra Crepidam. 1569. Traité de la Patience, Par Emblêmes, Inventées et dessinées par George Hoefnaghel à Londres, l'an 1569, Ms. en la Biblioteca Municipal de
} 
Fueron también los sambenitos colocados en la catedral de Granada los que dieron origen a la planta que ahora nos ocupa. Porque, en efecto, llevar el sambenito podía convertirse en el lema del mundo, suplantando su presencia. En la catedral, según se desprende de la documentación, aquéllos debían ser tan numerosos como para ocultar con su ostentosa y vergonzante presencia buena parte de la arquitectura y de los ornatos de la rotonda de la capilla mayor, especialmente en el deambulatorio, prácticamente la única parte construida hasta el momento. En 1594, el nuevo arzobispo de Granada, Pedro de Castro, en representación de los intereses del cabildo catedralicio y de la propia ciudad, incómodos, sin duda, ante semejante disfraz, se enfrenta a la Inquisición con el fin de conseguir retirar o situar en otro lugar los mencionados sambenitos, y ello no sólo con fines estéticos o de decoro que son los que ahora nos interesan ${ }^{33}$.

Pedro de Castro elevó sus quejas a Felipe II por la situación de los sambenitos, señalando que la durante la Semana Santa de 1594 no pudo conseguir que el Santo Oficio los retirase para decorar la catedral con los adornos apropiados al «ornato y excelencia que quiere Dios en su templo. No pudimos acavar nada con los inquisidores...». Indignado por tal situación le solicita la pronta retirada de los sambenitos con el fin de celebrar con decencia la próxima fiesta del Corpus Christi. Con este motivo, fue solicitada una planta de la catedral en la que debía figurar la situación de los sambenitos, planta que posiblemente realizara también Juan de la Vega. Vista la cual se propuso a la catedral la posibilidad de nuevas ubicaciones alternativas para aquéllos, sobre cuya pertinencia el arzobispo consultó de nuevo con Vega.

El aparejador de la Alhambra debía responder sobre las dificultades de la nueva ubicación propuesta y, si esto no era posible, sobre la conveniencia de situarlos en la «yglesia vieja», es decir en la mezquita mayor que entonces aún servía de Sagrario de la catedral. Por último, y un poco sorprendentemente, también se le requería para que informase sobre el estado de este último edificio.

Ambos documentos, el memorial y el dibujo que Juan de la Vega realizó para responder a las demandas solicitadas, constituyen el objetivo último de este breve estudio. Documentos enormemente reveladores desde un punto de vista conceptual e histórico, aportan datos preciosos sobre el estado de la catedral a finales del siglo XVI así como sobre la cultura arquitectónica de la época.

La planta es un dibujo a pluma, un rasguño, trazado a partir de un diseño previo, posiblemente también suyo ${ }^{34}$, sobre el que Juan de la Vega ha realizado un calco, como puede comprobarse por los rasgos de lápiz cubiertos por la tinta. Se trata de un dibujo, además, que no tiene un carácter proyectual, sino que se trata de un levantamiento incompleto del estado de la construcción para atender a un discurso no disciplinarmente arquitectónico, aunque subsidiariamente proporcione interesantes noticias en ese sentido. Todo lo cual revela, por otra parte, que la planta no es copia de ningún dibujo previo del proyecto, ya fuera debido a Siloe o a alguno de sus sucesores. Por otro lado, que no se trata de un dibujo levantado a partir de un plano proyectual anterior lo confirman la presencia del coro provisional en el deambulatorio, situación que se mantuvo hasta que no fueron construidas las naves de la iglesia catedral para cobijar el

Rouen. Citado y estudiado en F. Bouza, Catálogo de la exposición De Mercator a Blaeu. España y la Edad de Oro de la Cartografía en las Diecisiete Provincias de los Países Bajos, Madrid, 1995, págs. 141-143.

33 A. Domínguez Ortiz, «Los sambenitos de la catedral de Granada», en Miscelánea de Estudios Árabes y Hebraicos, XXVI-XXVIII, Fascículo 2, 1977-1979, págs. 315-318. Véase también el estudio de C. Maqueda Abreu, «La propaganda social del Santo Oficio», en E. Martínez Ruiz y M. de Pazzis Pi, Instituciones de la España Moderna 2. Dogmatismo e Intolerancia, Madrid, 1997, págs. 169-189. Ambos estudios usan la documentación conservada en el Archivo Histórico Nacional al respecto del caso granadino que nos ocupa.

${ }^{34}$ De la existencia de un dibujo anterior del mismo maestro, motivado también por el asunto de los sambenitos, escribe el propio Juan de la Vega en su Memorial (véase la transcripción en el Apéndice de este trabajo), señalando «...por donde se haçen las proçessiones en todo el año en la dicha yglesia nueba como esta referido y apuntado en el memorial y planta que yo envie a V. S. los dias pasados». 
espacio para el que lo había proyectado Siloe ${ }^{35}$, y el levantamiento de la planta del edificio de la mezquita mayor, un lugar en el que, según el proyecto de este último, debía ser ocupado por el Sagrario y el claustro de la catedral.

Sin embargo, las anteriores observaciones no implican un desconocimiento, por parte de Juan de la Vega, del proyecto original siloesco. De hecho debió tenerlo en cuenta al trazar en su planta la zona correspondiente a la nave, pilares, capillas laterales y fragmento de la fachada lindantes con la Capilla Real y la mezquita mayor o «iglesia vieja». Una zona en la que los cimientos de los pilares parece que estaban ya echados y comenzados a levantar, así como los correspondientes a los de la fachada, aunque las decisiones sobre los de la torre estaban, según Vega, aún por decidir, lo que constituye, sin duda, una importante novedad.

Es decir, el dibujo no ocupa su lugar lógico en el proceso del proyecto, sino que es a la vez testigo de lo construido e intérprete de lo proyectado. No muy riguroso en su trazo (el propio Juan de la Vega habla de «rasguño»), sí lo es en la escala y en la información constructiva y proyectual. Hay, sin embargo, un rasgo gráfico un tanto desconcertante en la representación de la planta cuya inexactitud puede deberse a diferentes y significativos motivos. Me refiero al hecho de que todas las columnas adosadas a pilares y muros aparecen representadas en planta, cuando la realidad es muy distinta ya que solamente las correspondientes a los pilares de las naves deberían haberse representado así al disponer de pedestales que continúan la sección circular de aquéllas, mientras que el resto se eleva sobre pedestales de sección recta.

La inexactitud señalada podría deberse a la rapidez de ejecución y al carácter del destino del dibujo, cuya finalidad, como sabemos, no era arquitectónica ni constructiva, lo que podría explicar la sorprendente alteración. Por otro lado, la identidad geométrica de la sección circular de los soportes en pilares y muros es frecuente en algunos otros proyectos siloescos, especialmente en la catedrales de Guadix y Málaga, lo que podría hablarnos de una primitiva disposición semejante en Granada, de la que sin embargo no poseemos documentación alguna, y que, a la postre, habría sido modificada por el propio Siloe ${ }^{36}$. Una disposición que podría haber sido representada en algún dibujo y ya hemos visto cómo Juan de la Vega debió hacer uso de un plano con un proyecto previo, no sabemos si el original, que sólo utilizó parcialmente para realizar el suyo.

También es posible, aunque inverosímil por la enorme sutileza y dominio de los sistemas de representación de la arquitectura que supone, que la planta la hubiera levantado a partir de una cota insólita como es la que puede situarse por encima de los pedestales, a la altura del imoscapo o de las basas de las columnas. Es más, casi dando la razón a esta sorprendente hipótesis aparece en el dibujo un alzado, escuetamente apuntado, del arco de acceso a las capillas radiales del deambulatorio con el fin de ilustrar el efecto que harían los sambenitos (identificados con las letras A y B) si así se colocaran, ocultando los capiteles y entablamento. En ese apunte no figuran tampoco los pedestales de las columnas, casi en justa correspondencia con la cota de la planta señalada, aunque, como ya he indicado, puede tratarse tan sólo de una imprecisión debida al carácter abocetado del dibujo y a los fines que debía cumplir en la polémica de los sambenitos ${ }^{37}$.

${ }^{35}$ El coro no se situó en el lugar proyectado por Siloe hasta 1620, aunque las obras ornamentales en él continuaran hasta el siglo XVIII con la construcción del trascoro por José de Bada. Su posterior desmantelamiento y traslado parcial a la rotonda se produjo en 1926 y, entre otras razones, se adujo para su cambio el hecho de que allí hubiera estado instalado durante el siglo XVI, sin que se conociera exactamente su disposición. Sobre este problema, véase E. E. Rosenthal, La catedral de Granada, op. cit, págs. 34-37.

${ }^{36}$ Véase al respecto F. Marías, El largo siglo XVI, op. cit., págs. 391-392.

${ }^{37}$ En todo caso, los errores e inexactitudes en la representación de edificios históricos no es exclusiva de una época histórica determinada. En España existe una carencia lamentable como es la de no disponer aún (?) de un corpus fiable de levantamientos de los más importantes edificios de su historia arquitectónica. Son muchos los historiadores que siguen usando los beneméritos dibujos de O. Schubert, de 1908, o los innumerables levantamientos contemporáneos casi siempre 
Al margen de las características y problemas que pueden advertirse en el dibujo de Juan de la Vega, otras noticias significativas aporta su traza. En primer lugar, gracias a él se puede conocer la disposición provisional del coro en el siglo XVI hasta que pudo ser situado en la nave central frente a la rotonda, lugar previsto por Siloe. Las imprecisiones documentales sobre su situación en la capilla mayor durante esa época han conducido a diferentes confusiones, unas incluso para avalar su traslado en 1926 al lugar que hoy ocupa en la rotonda, alterando así definitivamente el proyecto siloesco, y otras para acentuar el carácter temporal de su ubicación en la capilla mayor, como hiciera Rosenthal, aunque él lo situaba bajo el arco toral, inmediatamente antes del crucero. El dibujo de Vega, en cambio, lo dispone, como puede comprobarse, en el deambulatorio, entre la capilla absidal de San Cecilio y los pilares de la rotonda, lo que explica, por otra parte, que al deambulatorio se le llamase durante el siglo XVI trascoro ${ }^{38}$.

Según el dibujo, el coro estaba cerrado por dos sencillos muros y no debía ser de una altura demasiado elevada ya que el propio Juan de la Vega afirma en su memorial que los sambenitos «se verian de todas las sillas del choro desde adentro de el choro unos de unas sillas otros de otras». Pero, sin duda, esa localización no fue debida ni a consideraciones litúrgicas ni estaba destinada a tener consecuencias arquitectónicas. Se trataba, simplemente, de un coro provisional. Sin embargo, la disposición del mismo en la nave central, tal como había sido previsto en el proyecto de Siloe y, en efecto, fue construido, sí fue debida a razones litúrgicas y tuvo consecuencias arquitectónicas, hasta el extremo de comprometer visualmente el interior y la disposición centrípeta y centralizada del cuerpo de las naves, según la interpretación canónica más reciente, en la que han coincidido historiadores como Rosenthal, Nieto Alcaide, Marías o Tafuri. Lo que en la elevación y cubiertas parece evidente, a lo que habría que añadir la existencia del llamado segundo crucero y el diferente color, blanco, y la luz, diáfana, de las naves, enfrentadas al espacio también centralizado, circular, de luz coloreada y simbólico de la rotonda, quedaría desmentido en parte por la situación ritual y arquitectónica del coro. Un efecto espacial, compositivo y visual (Fig. 10) que hoy no podemos comprobar debido a la lamentable decisión, tomada en 1926, de desmontar el mencionado coro, cuya escala y dimensiones tenderían a negar la hipótesis de ese otro espacio centralizado en el cuerpo de las naves de la basílica y, sin embargo, insinuado por otras características arquitectónicas y ornamentales en las que ahora no me puedo detener, pero que ya fueron enunciadas en primer lugar por Rosenthal ${ }^{39}$ (Fig. 2).

El dibujo de Juan de la Vega plantea, además, otros problemas, tanto compositivos como constructivos que no hacen sino redundar en algo sobradamente conocido, la enorme pericia y

de una imprecisión insólita. Al respecto del tema de este trabajo, debo señalar que para una reciente exposición sobre la arquitectura andaluza del siglo XVI se hicieron innumerables planos de edificios, fundamentales muchos de ellos, de una sorprendente inexactitud, si exceptuamos, entre otros pocos, los correspondientes a la catedral de Granada (realizados por A. Almagro Gorbea, F. Salmerón Escobar y P. Salmerón Escobar). Verdaderamente lamentables resultan los relativos a la catedral de Málaga, siendo recomendable seguir usando los del siglo XVIII, debidos a A. Ramos. Y esto por poner un sólo ejemplo. Los dibujos mencionados pueden verse en el catálogo de la citada exposición Arquitectura del Renacimiento en Andalucía. Andrés de Vandelvira y su época, Sevilla, 1992.

${ }_{38}$ Véanse al respecto las observaciones de E. E. Rosenthal, La catedral de Granada, op. cit., págs. 35-36. Por su parte, M. Gómez-Moreno señalaba en su Guía de Granada, op. cit., pág. 266, que esa zona «se decía trascoro en el siglo XVI».

${ }^{39}$ La hipótesis de Rosenthal fue seguida y enriquecida con las aportaciones citadas de Nieto Alcaide, Marías y Tafuri. Sobre las consecuencias arquitectónicas y litúrgicas de la situación del coro en la arquitectura religiosa del siglo XVI véanse los reveladores estudios de A. Rodríguez G. de Ceballos, «Liturgia y configuración del espacio en la arquitectura española y portuguesa a raiz del Concilio de Trento», en Anuario del Departamento de Historia y Teoría del Arte, Universidad Autónoma de Madrid, vol. III, 1991, págs. 43-52 y «Liturgia y culto en las iglesias de Palladio», en Anuario del Departamento de Historia y Teoría del Arte, Universidad Autónoma de Madrid, vol. VII-VIII, 1995-1996, págs. 51-67. En el primero de ellos, sin embargo, A. Rodríguez de Ceballos señala que Siloe no dispuso el coro en la nave central, sino que su colocación en ese lugar fue debida a una decisión posterior, aunque de la documentación conocida no parece deducirse esa conclusión, incluso Rosenthal lo sitúa en aquella disposición en su restitución ideal del proyecto originario de Siloe, además de la confirmación que puede derivarse del memorial de Juan de la Vega. 
capacidad del arquitecto Diego de Siloe. De este modo, el dibujo, como ya he indicado, se hace eco no sólo del estado de la construcción en un momento determinado, sino que además incluye aspectos del proyecto original y de modificaciones del mismo inmediatamente posteriores cuya resolución concreta estaba aún por decidir, especialmente en lo relativo a la fachada, la torre y el Sagrario. La construcción de este último no se iniciaría hasta 1705, con trazas nuevas de Francisco Hurtado Izquierdo ${ }^{40}$.

Siloe proyectó y comenzó a construir un edificio «al romano» cuya ordenación arquitectónica y simbólica nacía no de un diseño ideal, sino que al idear una catedral y una capilla mayor con funciones funerarias imperiales tuvo que asumir algunos pies forzados, desde el perímetro gótico de Egas, entendido no sólo por sus consecuencias en planta, sino también por la escala y dimensiones de los volúmenes que aquél perímetro imponía ${ }^{41}$, hasta la presencia simbólica y efectiva de la Capilla Real, pasando por la de la mezquita mayor que, aunque destinada a desaparecer en su proyecto, para ser ocupada por el Sagrario y claustro de la catedral, mantuvo su presencia y sus consecuencias constructivas, afectando en menor medida a las primeras intenciones del diseño originario que al desarrollo posterior de la construcción.

Posiblemente una de las consecuencias más imprevisibles de la presencia de la «yglesia vieja» o antigua mezquita mayor pudiera ser la representada por el hecho de que las capillas hornacinas de las naves perimetrales no son idénticas en su profundidad en el lado del evangelio y en el de la epístola. Lo que no deja de ser extraño si pensamos que, al margen de la intocable Capilla Real, que ya sancionara Carlos V en los orígenes mismos del nuevo proyecto «al romano», la mezquita debía ser sustituida por el Sagrario y claustro en el diseño de Siloe, y debería haber permitido un trazado más profundo de las capillas hornacinas buscando la identidad simétrica con las correspondientes del muro norte.

Sin embargo, el muro muro meridional comenzó a levantarse a mediados del siglo XVII, antes de la demolición de la «yglesia vieja», antigua mezquita mayor, para ser sustituida por el Sagrario, definitivamente proyectado por Hurtado Izquierdo a comienzos del siglo XVIII. Ese hecho podría explicar la desigualdad entre las capillas, aunque del plano de Vega puede deducirse que esa asimetría estaba contemplada en el proyecto.

Las intenciones de Siloe en su proyecto, tal como ha sido reconstruido por Rosenthal, no parecen asumir la presencia de la vieja mezquita mayor, que en principio y lógicamente no debiera haberle afectado. En esa reconstrucción del proyecto originario, basado fundamentalmente en lo expuesto por Lázaro de Velasco en el concurso de 1577, Rosenthal establece una secuencia de tres capillas adosadas al muro exterior de la catedral como espacio para el Sagrario, cuyo eje central y compositivo debía atender tanto al axial de la Capilla Real, desde la que debería verse el Sagrario, como al transversal del segundo transepto, cuya entrada simbólica y real sería la puerta de San Jerónimo, construida por Siloe y situada en el muro norte. Un transepto que, según Rosenthal, debía funcionar como nave de la capilla del Sagrario.

Es decir, todo ello indica que en su proyecto, tal como es descrito por Lázaro de Velasco, Siloe planteó la construcción de un Sagrario atento no tanto a la presencia de un edificio anterior, destinado a desaparecer, cuanto a dos ejes visuales, rituales y representativos, el la Capilla Real y el del segundo transepto, que debían cruzarse en el centro de la capilla central del Sagrario, lo que le obligó a desplazar hacia el interior de la catedral el muro perimetral haciendo así con menor profundidad las mencionadas capillas hornacinas. Es decir, no fueron las exigencias normativas del diseño arquitectónico las que controlaron exclusivamente el proyecto

${ }^{40}$ R. Taylor, «El Sagrario de la Catedral de Granada y la Junta de Maestros de 1738», en Anuario del Departamente de Historia y Teoría del Arte, U. Autónoma de Madrid, vol. VII-VIII, 1995-1996, págs. 149 y ss.

${ }^{41}$ Véase, al respecto, F. Marías, «De iglesia a templo...», op. cit. 125 y ss. 
arquitectónico, sino que esas exigencias (tipológicas, geométricas, proporcionales o de lenguaje arquitectónico) tuvieron que someterse a necesidades religiosas, litúrgicas y simbólicas capaces de comprometer la corrección de un diseño. Extraer consecuencias arquitectónicas y adaptar los lenguajes y espacios a requerimientos imaginarios, simbólicos y rituales fue la gran aportación de Siloe, aunque esa actitud le obligase a transgredir las reglas de una arquitectura «a lo romano». No es, por tanto, en términos de centro y periferia, entendidos en relación a la distancia que pudiera existir entre la arquitectura de vanguardia italiana y la arquitectura española, o mejor de Siloe, como puede explicarse su arquitectura, sino en función de su interpretación y adaptación de aquellos modelos a exigencias culturales e históricas diferentes, incluso simbólica e históricamente centrales, por no hablar de las específicamente constructivas. A fin de cuentas también se trataba de construir una catedral en piedra y en ese punto sus conocimientos estereométricos de la tradición gótica le permitieron proporcionar una respuesta clásica y «romana», aunque para ello debieran alterarse algunas reglas canónicas ${ }^{42}$.

Es más, el dibujo de Juan de la Vega nos sirve también para confirmar la disposición de las tres capillas del Sagrario ya que el trazado exterior del muro perimetral no es recto ni tiene adosado el de la mezquita mayor, aún en pie en esa época, sino que recoge las decisiones marcadas en el proyecto de Siloe, haciendo visibles los retranqueos murarios correspondientes a las tres capillas que debían ser situadas en los ejes antes mencionados, siendo el tramo correspondiente a la central, la del Sagrario, con puerta abierta al interior de la catedral, el más complejo y rico en su articulación muraria. De haberse mantenido la simétrica profundidad de las capillas ese muro tendría que haberse desplazado hacia el eje de la puerta de Capilla Real, modificando la centralidad visual del Sagrario desde ese espacio fundamental en la historia arquitectónica y litúrgica del complejo catedralicio. Todo lo cual concuerda, en términos generales, con la restitución hipotética propuesta por Rosenthal en su fundamental estudio sobre la catedral de Granada.

El dibujo de Juan de la Vega, a pesar de su descuidada ejecución, es un verdadero palimpsesto que nos permite ver lo real y lo proyectado confundidos y comprometidos con la historia. Un peculiar dibujo, a medias retrato, levantamiento de lo construido, y proyecto, y traza también funcional, incluso compedio de ulteriores transformaciones. Un «rasguño» que también explica

42 En demasiadas ocasiones los historiadores de la arquitectura han interpretado las soluciones de la construida en la península durante el siglo XVI como imprecisiones periféricas con respecto a modelos italianos, cuando habría, en primer lugar, que diversificar esos modelos y, por otro, atender a las diferentes formas de apropiación del clasicismo, en muchas ocasiones usadas para responder a situaciones históricas y culturales muy diferentes. Por otra parte, no debe desdeñarse tampoco la propia tradición constructiva, desde la estereometría a la misma organización del trabajo, marcada necesariamente por la historia más reciente. En Francia, revisiones semejantes de esos tópicos habituales condujeron a J. M. Pérouse de Montclos a hablar de una «manera francesa» de construir en su brillante y polémico L'architectura à la française. XVIe, XVIIe, XVIIIe siècles, París, 1982. Con posterioridad puede verse el sugerente estudio de J. Guillaume, «Les Français et les ordres, 1540-1550», en J. Guillaume (ed.), L'emploi des ordres dans l'architecture de la Renaissance, París, 1992, págs. 193-217. El propio M. Tafuri, en sus dos estudios sobre el palacio de Carlos V y la arquitectura granadina, ya citados, revisó sus posiciones «centralistas», pertinentes con respecto al palacio de Machuca, y, sin embargo, en relación a Siloe y la catedral de Granada, escribió: «Né Siloe è un vitruviano, beninteso. Dovremo concludere che per il suo linguaggio - come per quelli di Andrés de Vandelvira e di Hernán Ruiz il Giovane — la categoria dell'eclecttismo non spiega nulla. Appare piú proficuo riconoscere a Siloe un'originalità dovuta ad approcci talora ingenui alla manera all'antica ma dotati di una libertà consentita — paradossalmente - dal loro innesto in tradizioni compositive e costruttive di diversa tradizione», en M. Tafuri, «La Granada di Carlo V...», op. cit., pág. 274. Y todo ello, a pesar de insistir, como también hiciera con anterioridad F. Marías (El largo siglo XVI), en la derivación de su cultura arquitectónica de las propuestas de Antonio y Giuliano da Sangallo, especialmente en relación a los proyectos para San Pedro del Vaticano del primero. En este contexto no conviene olvidar las precisas observaciones sobre Siloe y su catedral de Granada, con un viejo y escueto lenguaje característicos de su escritura, de M. Gómez-Moreno, Las águilas del Renacimiento español, op. cit., págs. 69 y ss. Por otra parte, y para finalizar esta ya demasiado larga nota, debo señalar que su intención está muy alejada de otras recientes posiciones metodológicas e historiográficas que ya han sido advertidas por F. Marías, calificándolas muy afortunadamente como propias de «una historiografía autárquica». 
cómo el proyecto de Siloe pudo ser alterado a lo largo de su construcción, ya fuera por él mismo o por algunos de sus continuadores en la maestría mayor y, en todo caso, a partir del concurso de 1577 parece que se abriera un período de indecisiones proyectuales que aún estaban pendientes de solucionar en los años en los que hizo Juan de la Vega su planta. Y esto ocurría, sobre todo, en la zona mencionada, conociendo, además, que Siloe no dejó diseño alguno, o al menos no se conservaban en 1577, del Sagrario y claustro. El único que, como hemos visto, parecía conocer las intenciones del arquitecto fue Lázaro de Velasco.

Especialmente reveladora resulta, en ese sentido, la observación contenida en el memorial de Juan de la Vega, refiriéndose al estado en el que se encontraba el edificio de la antigua mezquita, señalando que su conservación era buena y que «aun antes tiene más sitio porque esta por elegir la Torre de la yglesia mayor nueva que junta con la dicha yglesia vieja y un lado de la pared de la dicha torre Donde esta el caracol F como va señalado en la plantilla». De hecho esa elección fue definitivamente aprobada mucho más tarde, en 1667, cuando Alonso Cano proyectó la fachada de la catedral $^{43}$. Mientras tanto, en un momento impreciso entre 1577, cuando aún todos los participantes en el célebre concurso mantenían las dos torres idénticas en sus proyectos, y 1594, fecha del dibujo de Vega, debió plantearse la posibilidad de reducir la dimensión en planta y alzado de la torre vecina al Sagrario. Mientras se tomaba esa decisión, el dibujo incorpora la torre tal como fue proyectada por Siloe, idéntica en su diseño a la construida, según se desprende del mencionado dibujo de A. de Vico realizado en 1590. Identidad en los retranqueos exteriores, posteriormente macizados, así como en la distribución interna y en la articulación de pilastras y columnas en los muros correspondientes al interior de la catedral. Pero también plantea la traza, con una línea de puntos, una drástica reducción de la torre, tal vez con el fin de acoger un proyecto diferente de Sagrario (posiblemente debido a Juan de Orea o, aunque es más extraño, a Vico), anticipándose casi un siglo a la decisión tomada con motivo de la aprobación del proyecto de Alonso Cano para la fachada.

En otras palabras, el dibujo de Juan de la Vega presenta características del proyecto que a la postre serían construidas tal y como aparecen representadas en él, incluyendo los pilares, el muro perimetral, las capillas lindantes con la mezquita mayor, levantadas en los años centrales del siglo XVII, al menos hasta la primera cornisa, y la mencionada reducción de la torre que asumiría el proyecto de Cano (Fig. 13). Todo lo cual podría confirmar que muchas de las decisiones que se tomaron en el siglo XVII ya habían sido planteadas con anterioridad a la fecha de la planta dibujada por Juan de la Vega, en un momento indeterminado de la segunda mitad del siglo $\mathrm{XVI}$, marcando decisivamente el desarrollo posterior de la construcción de esa zona e influyendo notablemente, además, en la volumetría y en la composición con el motivo triunfal de la fachada proyectada por Alonso Cano ${ }^{44}$. Por otro lado y en relación a la fachada, el dibujo de Juan de la Vega, aporta una ulterior precisión en relación al proyecto de Siloe. Me refiero al diseño en planta del machón o estribo extremo de la entrada lateral, cuya dimensión y articulación

${ }^{43}$ Sobre el proyecto de A. Cano para la fachada de la catedral de Granada véanse, entre otros estudios, el ya citado de Rosenthal, op. cit., págs. 55 y ss., así como H. E. Wethey, Alonso Cano. Pintor, escultor y arquitecto, Madrid, 1983; la reconstrucción hipotética del proyecto de Cano en R. Taylor, «El arquitecto José Granados de la Barrera», en Cuadernos de Arte, Universidad de Granada, XII, 1975, págs. 5-14 y fig. 14 y D. Sánchez Mesa, «La portada de la Catedral de Granada como el gran retablo barroco de Alonso Cano», en Estudios de Literatura y Arte dedicados al profesor Emilio Orozco Díaz, Granada, 1979, t. III, págs. 307-322.

${ }^{44}$ A propósito de la fachada de A. Cano se ha discutido con frecuencia hasta qué punto asumió el proyecto de Siloe, algo suficientemente aclarado, en mi opinión, por Rosenthal, y si pudo también tener en cuenta la composición de la fachada triunfal de la Real Colegiata de Santa María de Antequera, construida entre 1514 y 1550, cuyo extraño diseño tan próximo parece al de Cano. Aunque es posible que la fachada de la iglesia de Antequera (Fig. 12) pudiera haberse inspirado en el proyecto de Siloe para la de Granada, también lo es que ambas tuvieran una fuente común, no sólo de origen italiano, como hasta ahora se ha supuesto, sino también posiblemente francés, especialmente a partir de fuentes gráficas. Recuérdese, al respecto, la presencia de artesanos franceses en la construcción de la maqueta de la catedral de Granada y la enorme frecuencia con la que maestros canteros franceses aparecen en la construcción de edificios andaluces durante el siglo XVI. 
muraria tan distinta resulta tanto de la solución construida como de la atribuida a Siloe por Rosenthal. En ambas, en efecto, el estribo aparece considerablemente reducido, cortado de manera brusca, elocuente arquitectónicamente en su perfil próximo a la puerta lateral, pero mudo en su cara próxima a la torre. Mientras que el dibujo de Vega corresponde, en planta, a un diseño de fachada absolutamente distinto, coincidente con lo realizado en época de Siloe, posteriormente alterado en la fachada de Cano que no necesitaba de un soporte semejante para lograr su elevación, mucho más esbelta que la que había proyectado el arquitecto de la catedral.

Otros datos importantes manifiesta el dibujo y el memorial que lo acompaña de Juan de la Vega, especialmente en relación a la disposición y usos de la mezquita mayor o «yglesia vieja». Una primera planta de esa construcción la publicó Manuel Gómez-Moreno en su Guía de Grana$d a$, pero en ella se representaba el estado de la misma en 1705, después de diferentes modificaciones y alteraciones sufridas a lo largo del siglo XVII ${ }^{45}$. La que incorpora Vega en su dibujo no sólo nos habla de su estado y funciones en el siglo anterior, sino, además, de las consecuencias arquitectónicas de su presencia en el proyecto global de la catedral de Granada, como ya he señalado.

Muchos otros problemas plantea aún la planta de Juan de la Vega y su memorial, transcrito completo al final de este estudio, sobre todo en relación a los órdenes de la catedral de Granada, de los que llega a afirmar que, cubiertos por los sambenitos, no se verían «las columnas que son los miembros prinçipales y la hermosura de todo el edifiçio». Sirvan estan notas, por otro lado, para recuperar la emoción por una catedral excepcional en la cultura europea del siglo XVI, así como por la obra de un arquitecto como Siloe que supo conciliar el sistema de los órdenes clásicos y la tradición arquitectónica, de tal forma que el módulo constituido por aquéllos aparece como principio compositivo de un edificio que podía haberlos usado exclusivamente con una función ornamental ${ }^{46}$. Algo de lo que, sin duda, era consciente Juan de la Vega al comentar críticamente su ocultación por los sambenitos. Un proceso que duró hasta 1611, año en el que fueron definitivamente retirados, cuando ya Pedro de Castro era arzobispo de Sevilla, lo que no le impidió demostrar un no ocultado entusiasmo por su tardío triunfo, devuelta la catedral «a su antigua herrmosura y resplandor, et abstulit opprobium que la tenía tan afeada» ${ }^{47}$.

\section{APÉNDICE}

\footnotetext{
Memorial de Juan de la Vega al Arzobispo de Granada Don Pedro de Castro, firmado el 28 de abril de 1594.

«En este memorial va Respondido a los apuntamientos que V.S. manda por su memorial y planta es lo siguiente.
}

${ }^{45}$ M. Gómez- Moreno, Guía de Granada, op. cit., pág. 282 y ss. El plano fue retocado por Gómez-Moreno con el fin de introducir las denominaciones de cada una de las partes del antiguo Sagrario, fechándolo en 1704. Con posterioridad el plano ha podidò ser reproducido fielmente por A. Gallego Burín, Granada. Guía histórica y artística, op. cit., pág. 248 y, por fin, fechándolo en 1705, y con una transcripción de algunos documentos que explican lo que allí se encontraba antes de su destrücción, por E. Isla Mingorance, «Noticias sobre el antiguo Sagrario de la Catedral de Granada», en Cuadernos de Arte, Universidad de Granada, XII, 1975, págs. 125-140.

46 Tampoco del siglo XVIII se conservan, $\mathrm{o}$ al menos no se conocen, dibujos de la catedral ni del nuevo proyecto del Sagrario, a excepción de uno relativo a la torre de aquélla, conservado en el Museo catedralicio, con copia en la Fundación Rodríguez Acosta. El dibujo fue reproducido en A. Gallego Burín, Granada, op. cit., pág. 256, y es, sin duda, una copia de otro anterior, posiblemente del siglo XVI. Sobre este dibujo véase también M. Gómez-Moreno Calera, El arquitecto granadino Ambrosio de Vico, op. cit., pág. 37. Sobre la planta de la catedral levantada por José de Hermosilla (Fig. 7) en 1766 y sus observaciones al respecto, véase mi estudio La memoria frágil. José de Hermosilla..., op. cit., págs. 89 y ss.

${ }^{47}$ Citado en A. Domínguez Ortiz, «Los sambenitos...», op. cit., pág. 26. En la misma carta, escrita en Sevilla en 1611 y dirigida por Pedro de Castro al Inquisidor General, señala: «Agora edificara yo muy de buena gana lo que resta de la Iglesia en honra y nombre de V. S. Ilma. que de sinagoga la ha hecho templo sagrado...» (A. Domínguez Ortiz, op. cit., pág. 26). 
1. Lo primero que los sambenitos que al presente estan puestos en la yglesia mayor de Granada si se podrian poner y Repartir en los pilares y ençima de los arcos como viene apuntado en la plantilla con las letras AA y BB. A esto se Responde que haçer esto y ponellos y Repartillos en los dichos lugares ternian inconvinientes. Seria estar todos los pilares y arcos de toda la capilla de el traschoro de ella salpicados con sambenitos y no abria lugar en toda la capilla que no se biesen los sambenitos y seria lastima ver un edifiçio tan galano colgado de paños tan feos y quedaria la capilla y traschoro tan fea y mas de lo que agora lo esta. Porque haçiendolo y puniendolos se an de dividir en muchas partes y no abra pilar ni arco que no tenga sambenitos y se verian de todas las sillas del choro desde adentro de el choro unos de unas sillas otros de otras y ansimismo quedarian tapados los encasamentos o nichos que estan en los intercolumnos que es el espaçio que ay entre una columna y otra que alli se an de poner figuras de sanctos y tapandolos con los sambenitos no se pueden poner ni ver y tambien se tapan las columnas que son los miembros prinçipales y la hermosura de todo el edifiçio. Y encima de los arcos de las capillas en la letra $\mathrm{G}$ estan unos compartimentos donde se an de poner los titulos de las capillas y poniendo alli los sambenitos nadie las comprara por la divisa que tendran ençima y quedarian puestos de un lado y de otro por donde se haçen las proçessiones en todo el año en la dicha yglesia nueba como esta referido y apuntado en el memorial y planta que yo envie a V.S. los dias pasados.

2. Lo sigundo que diçe que quando no cupiesen en los pilares y ençima de los arcos que se pongan tambien en las dos paredes de los lados de el coro por la parte de fuera señaldos con CC. A esto se Responde que en aquellas paredes no se pueden poner ningunos sambenitos porque son muy vajas que se hicieron solo para atajar el choro de prestado hasta que lo muden donde a de estar y tienen los organos en lo alto de ellos que es de forma como de valcones. I

3. Lo terçero que diçe que tambien se pueden Repartir en el transito de la puerta $G$ en las paredes señaladas con las letras DD. A esto se Responde que es un espaçio muy pequeño de una capilla hornezina y ansi ay muy poquito lugar para ponerlos alli que no cabrian una deçima parte de los que ay.

4. Lo quarto que diçe que se mire y advierta si se podrian poner en la yglesia vieja que agora sirbe de sagrario adonde antes estavan. A esto se Responde que atenta la capaçidad de el edifiçio se pueden poner y Repartir en las naves de la dicha yglesia vieja donde solian estar antes que los pasasen a la yglesia nueba. Sino ympide que se veran los dichos sambenitos o parte de ellos desde la Real capilla que junta con la dicha yglesia vieja. Asimismo alli asiten las cofradias de el sanctisimo sacramento y se haçen en el dicho templo muchas fiestas solemnes de devoçion y se cuelga la mayor parte de la dicha yglesia y quiza çesarian estas fiestas y cofradias si se colgasen alli los sambenitos porque perderian la devoçion y en la mesma yglesia vieja esta la pila de el Baptismo donde se baptizan la gente mas principal de toda la çiudad por ser parrochia mayor y en semejantes dias se cuelga y haze muchas fiestas y asimismo vienen a la dicha yglesia vieja toda la clereçia y cabildo en proçesion a vendeçir la pila dos pascuas de el año y adereçan la nave de la pila y se pusiesen en ella los sambenitos no se podria colgar ni adereçar pero si a su Mag. le paresçiere y fuere serbido y viere que lo dicho no es inconviniente digo que en quanto al edifiçio se podrian poner en la dicha yglesia vieja como lo estavan antes.

5. Lo quinto que diçe que si la yglesia vieja esta derrivada alguna parte de ella o le faltan alogunas columnas a esto se Responde que no esta derrivada y que esta cubierta toda y que al presente reparan parte de una nave y que columnas no le faltan ningunas sino que esta de la forma que fue traçada en la planta que yo embie a V.S. y aun antes tiene mas sitio porque esta por elegir la Torre de la yglesia mayor nueva que junta con la dicha yglesia vieja y un lado de la pared de la dicha torre Donde esta el caracol F como va señalado en la plantilla con unos puntos en la dicha Torre quando se elija viene a tomar un poco el sitio de la dicha / yglesia vieja y ansi agora tiene mas sitio todo lo que occupa aquel pedaço de pared y caracol Pero todo lo demas esta como fue traçado en la planta que V.S. tiene alla.

Juan de la Vega» 


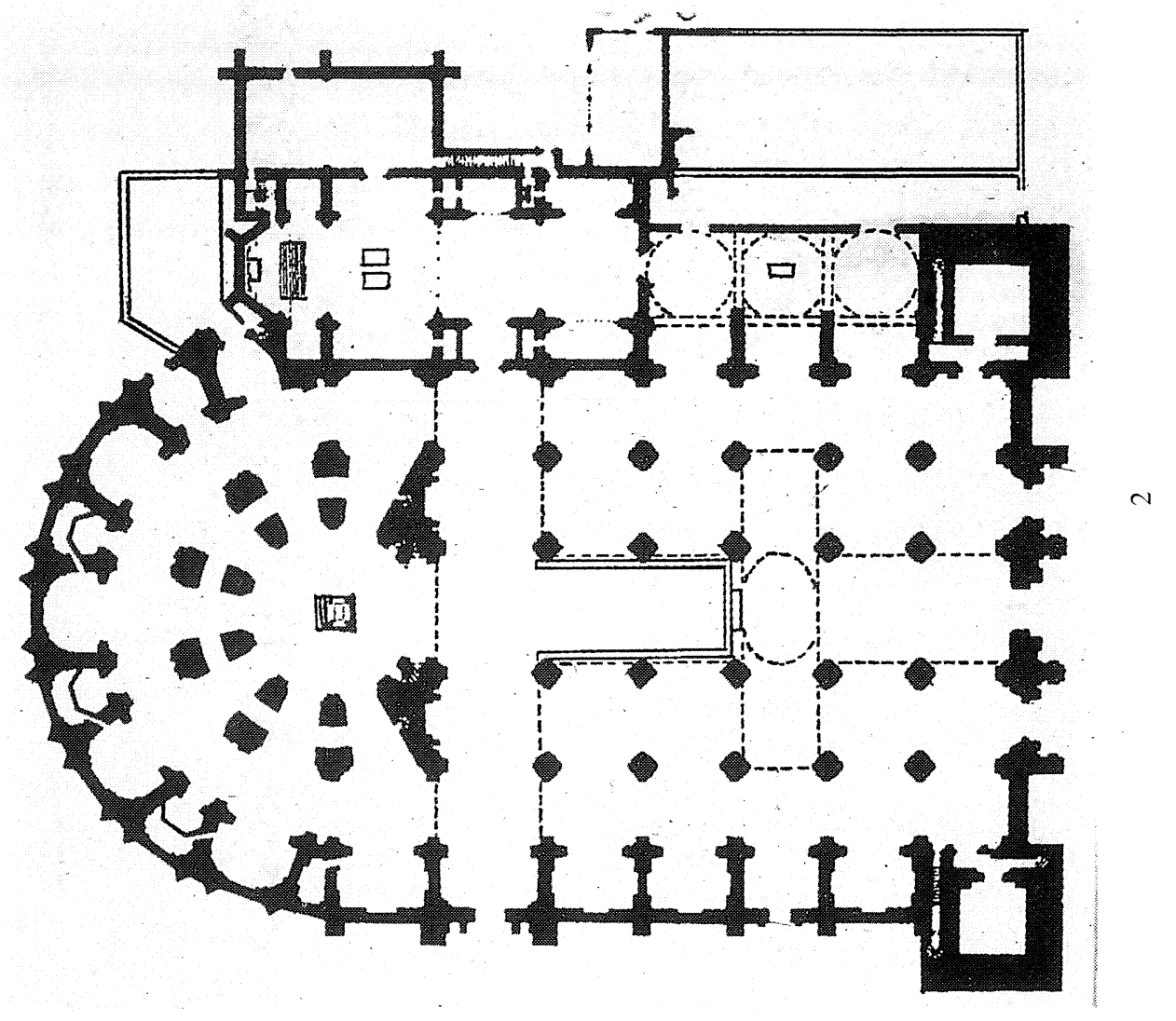

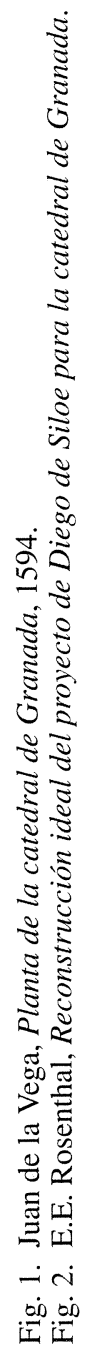

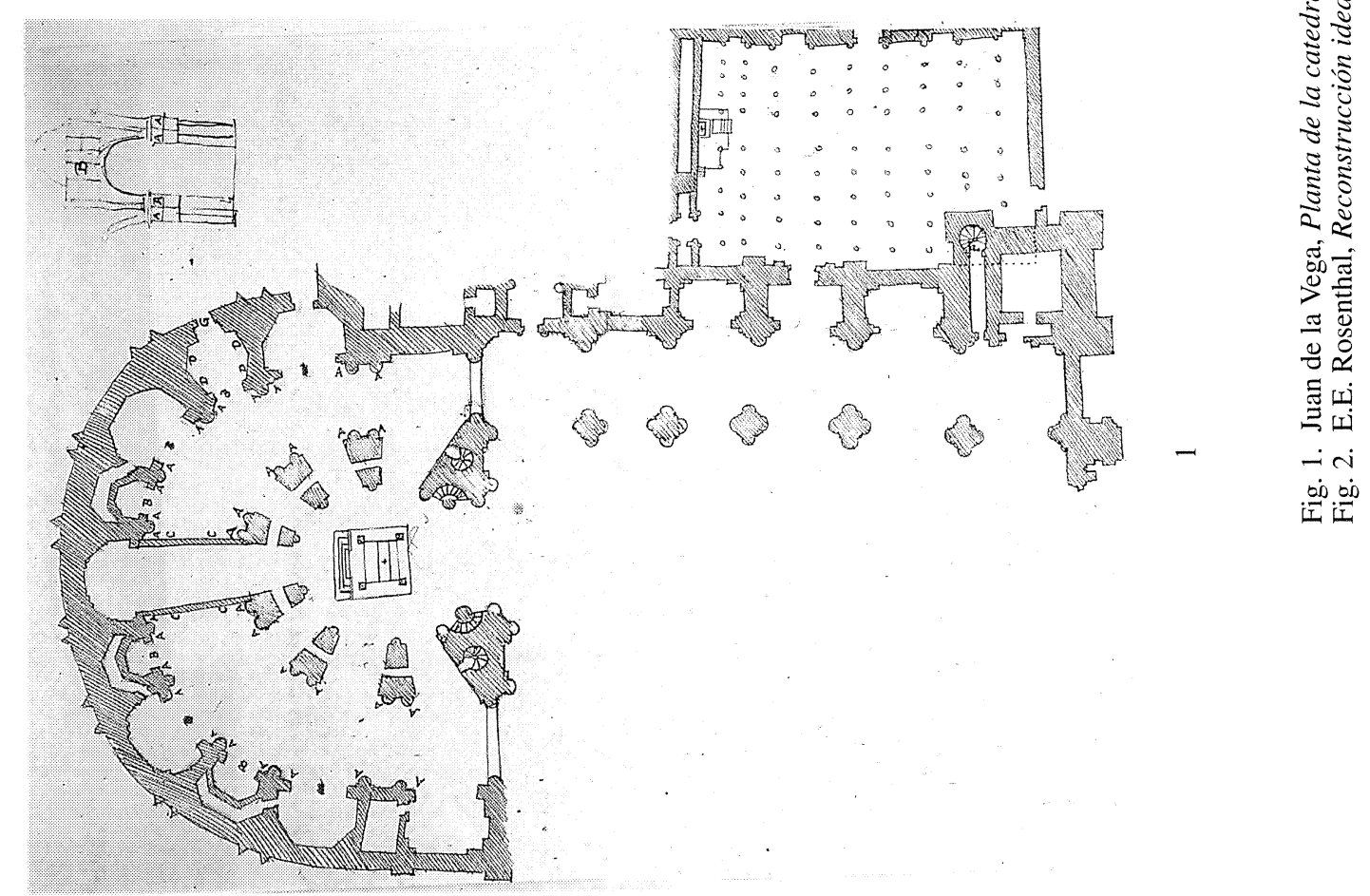



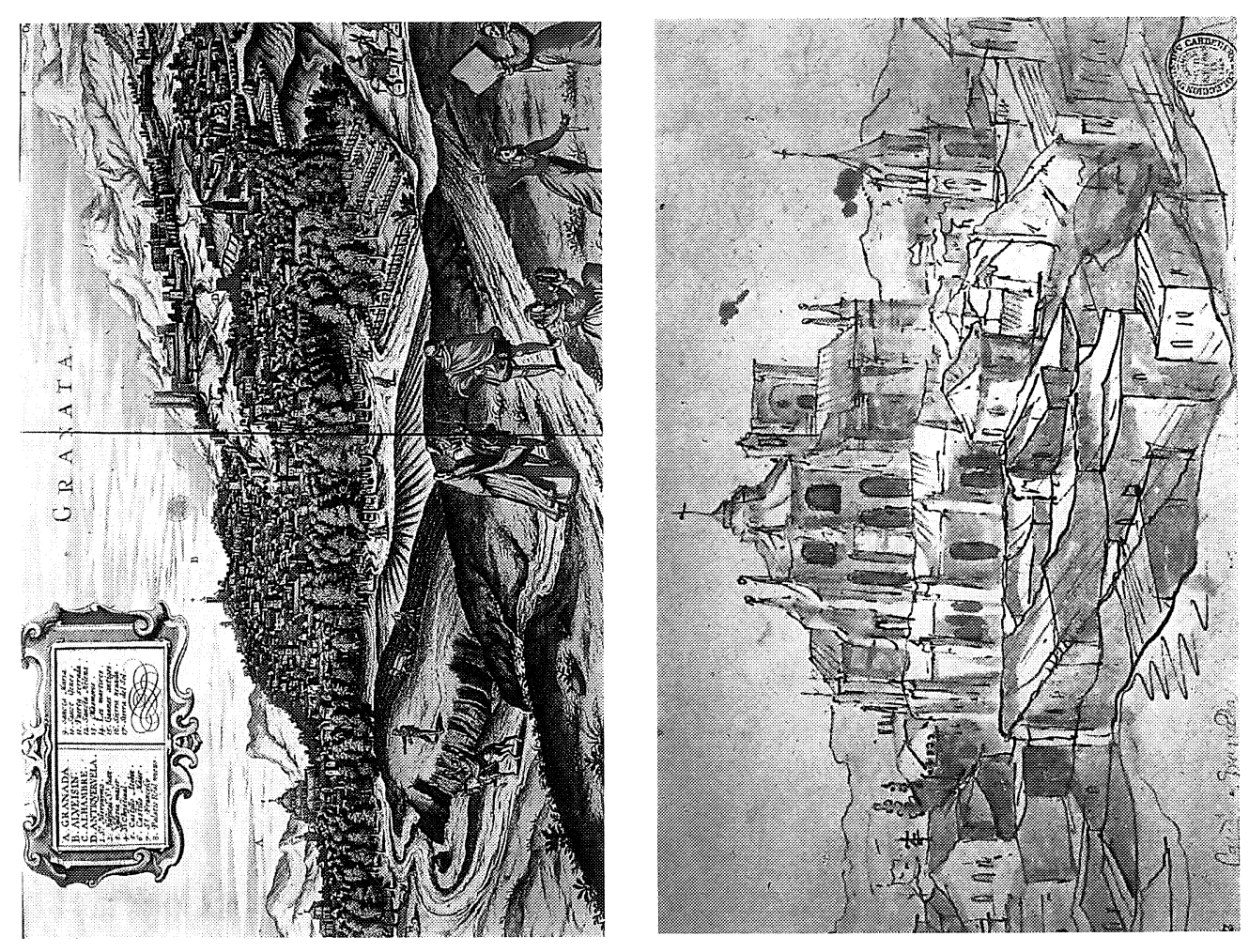

ํํำ

in

흥

हิ

हैं

0

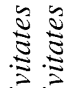

نे

क⿺⿻一⿰冫⿰亅⿱丿丶丶⿱⿰㇒一乂

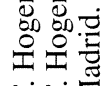

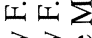

论志志要

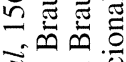

ல்ن்

ธี ฮี

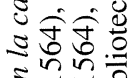

m
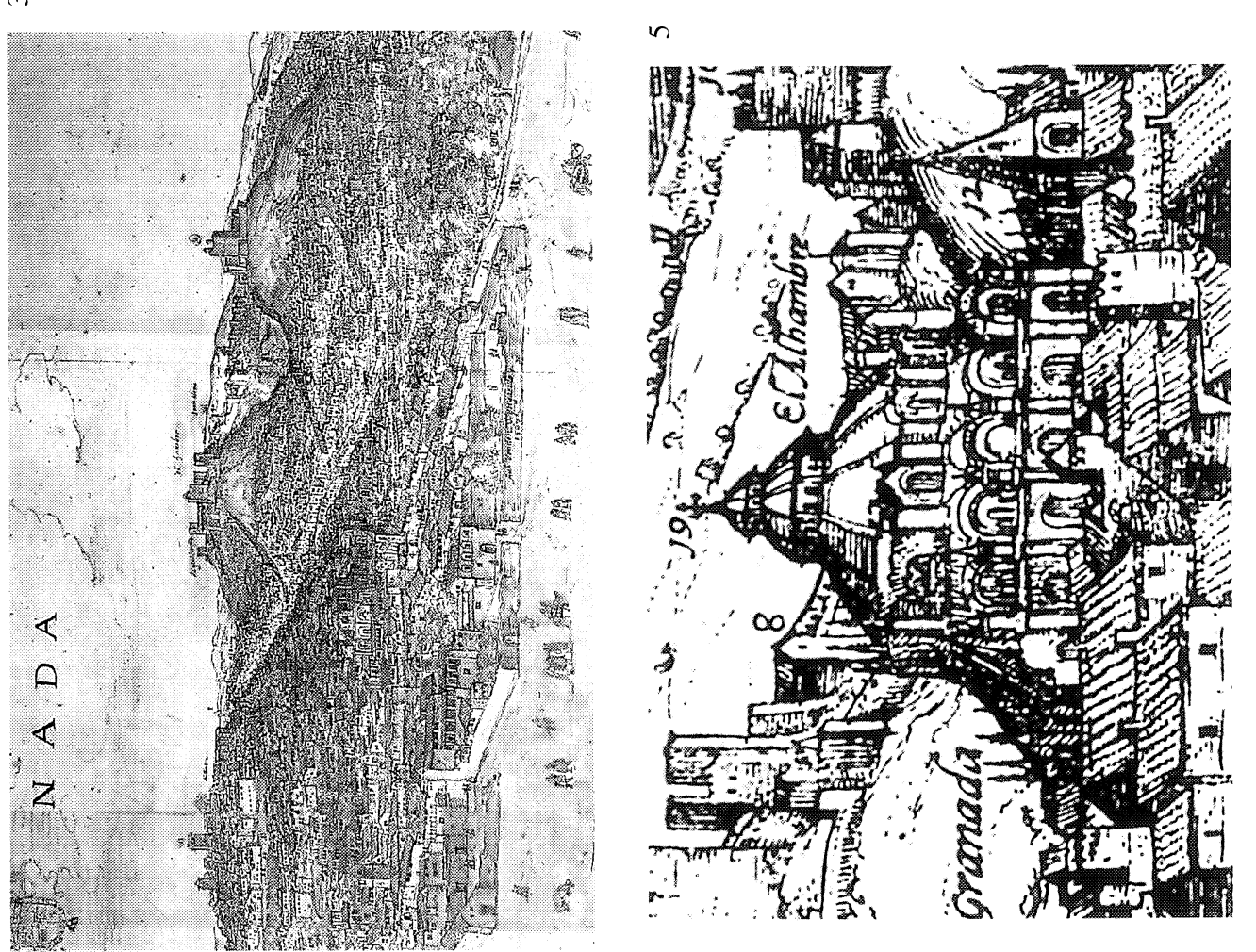

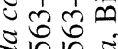

원ํำ

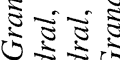

ช

胥

ชิ

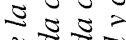

ะ

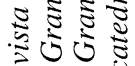

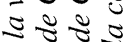

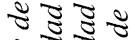

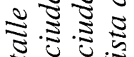

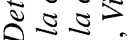

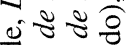

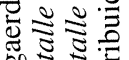

ฮัง

过

도용

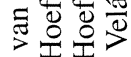

岩出官

rifin

on 


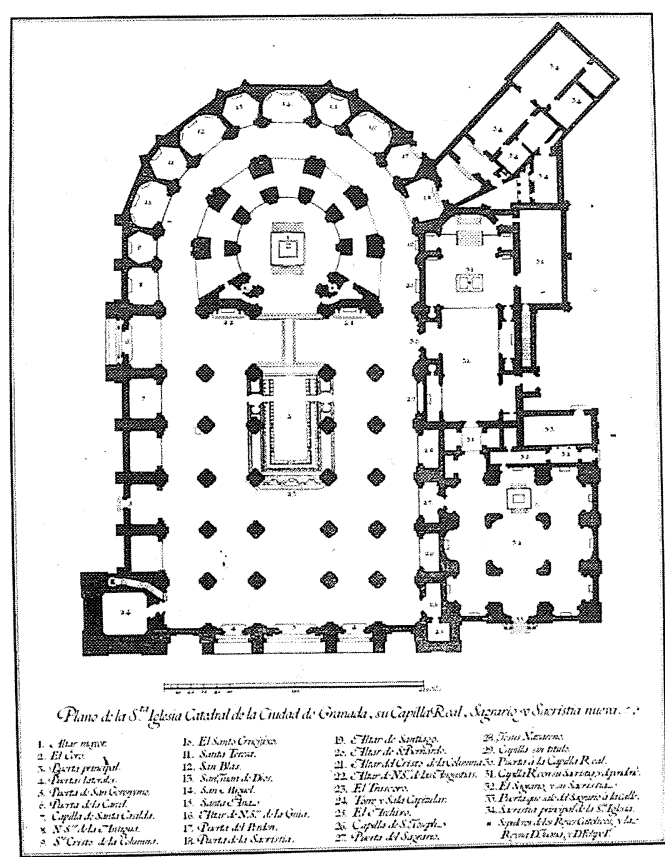

7

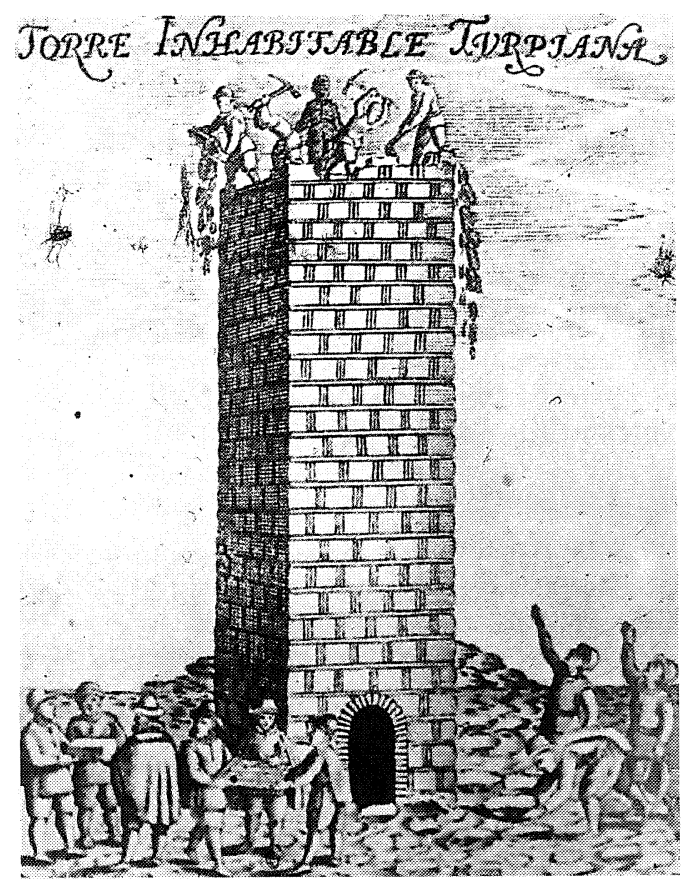

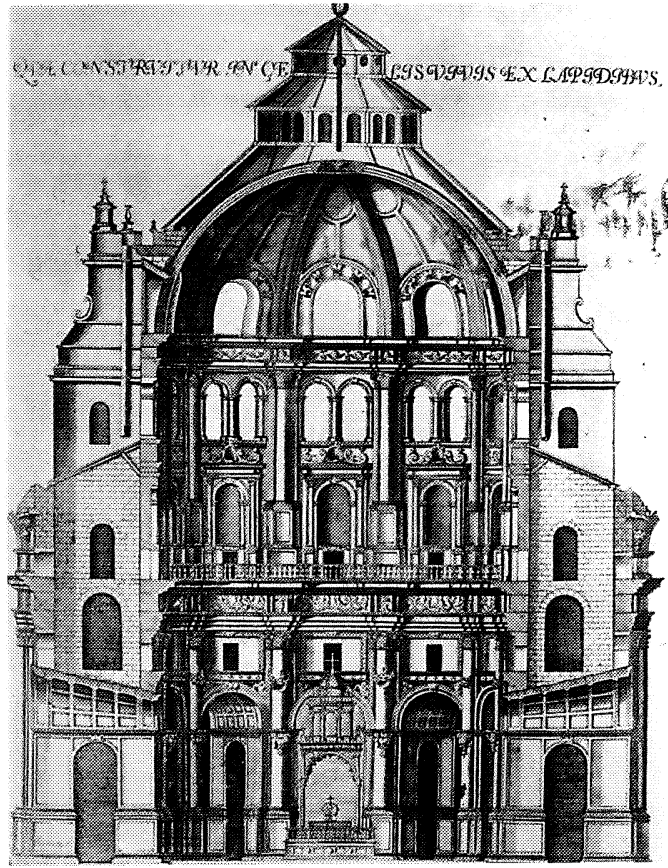

8

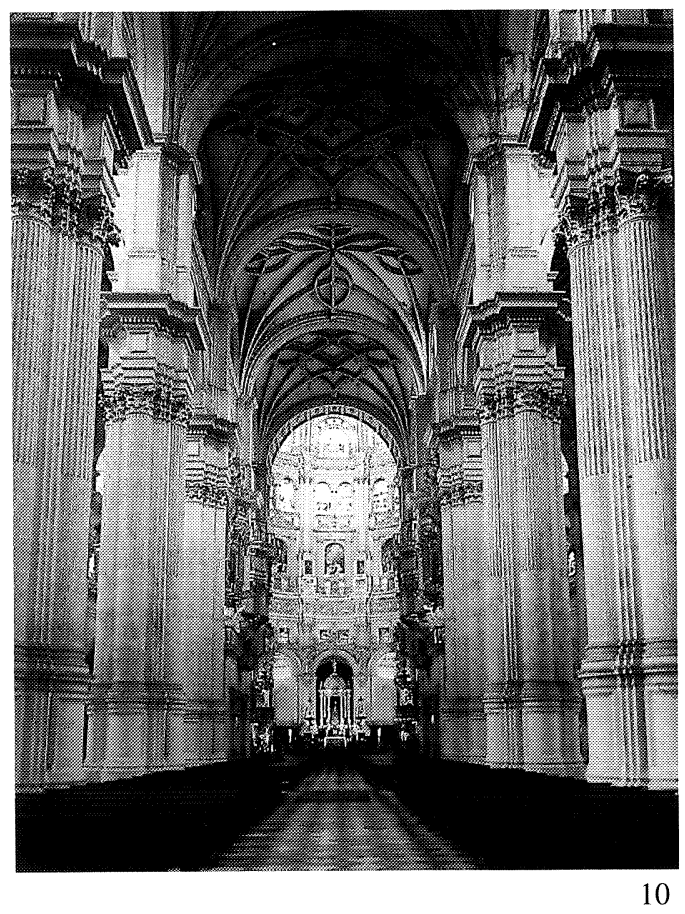

Fig. 7. José de Hermosilla, Planta de la catedral de Granada en 1766.

Fig. 8. A. de Vico (?), Sección de la capilla mayor de la catedral de Granada, grabada por F. Heylan hacia 16131614.

Fig. 9. Anónimo, Torre Turpiana, grabada por F. Heylan.

Fig. 10. Interior de la catedral de Granada. 

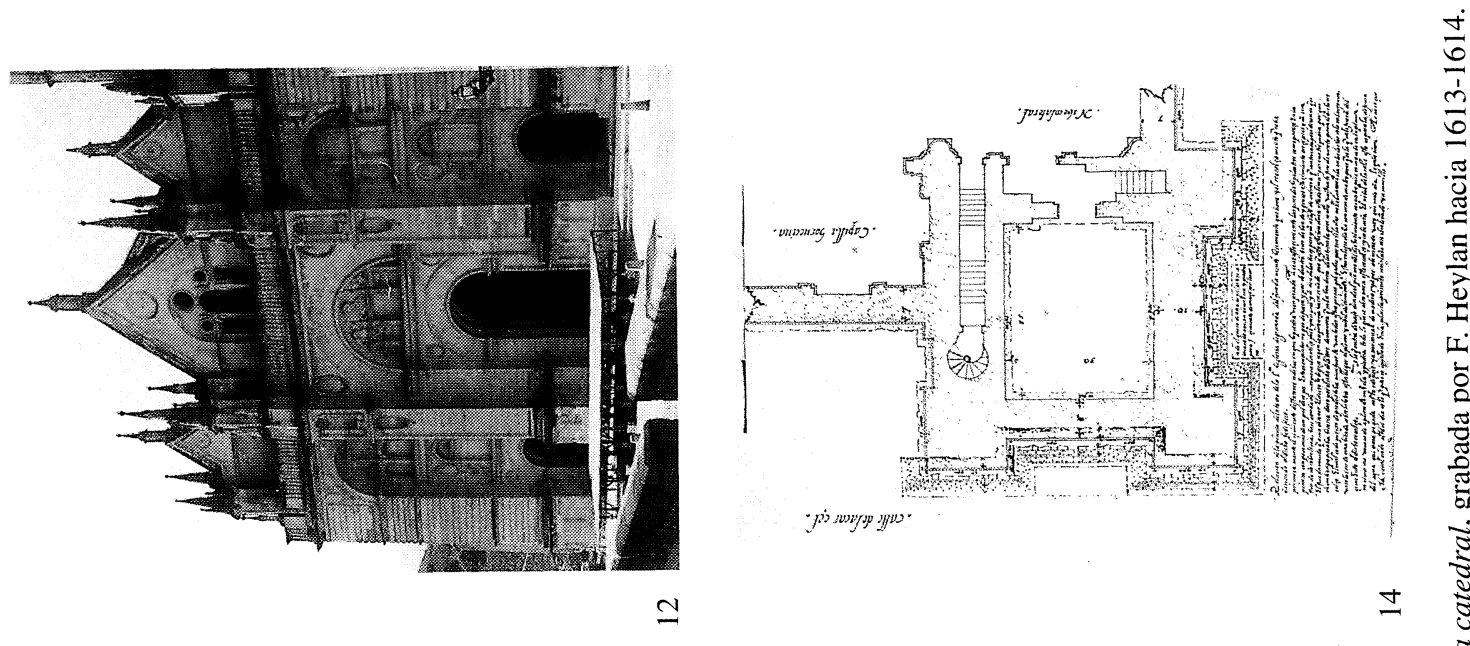

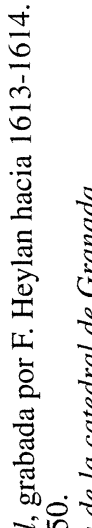

ฐี่

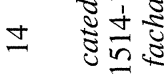

$2 \div$

\%

胥

跣记

屯ㅇ

$=$

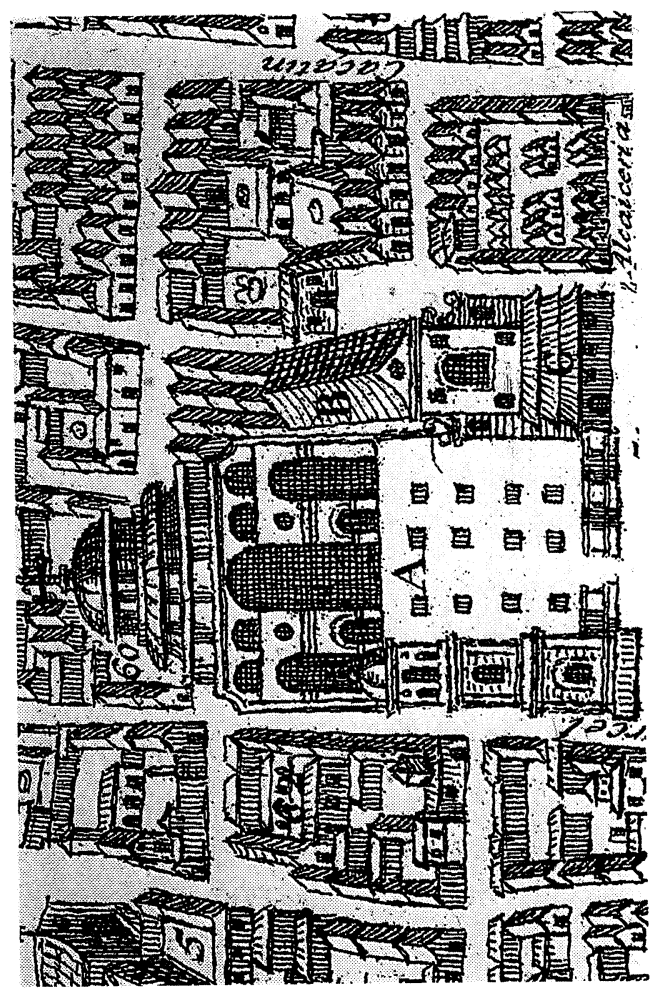

2

娄花

ฐ) ะ ะ

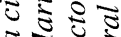

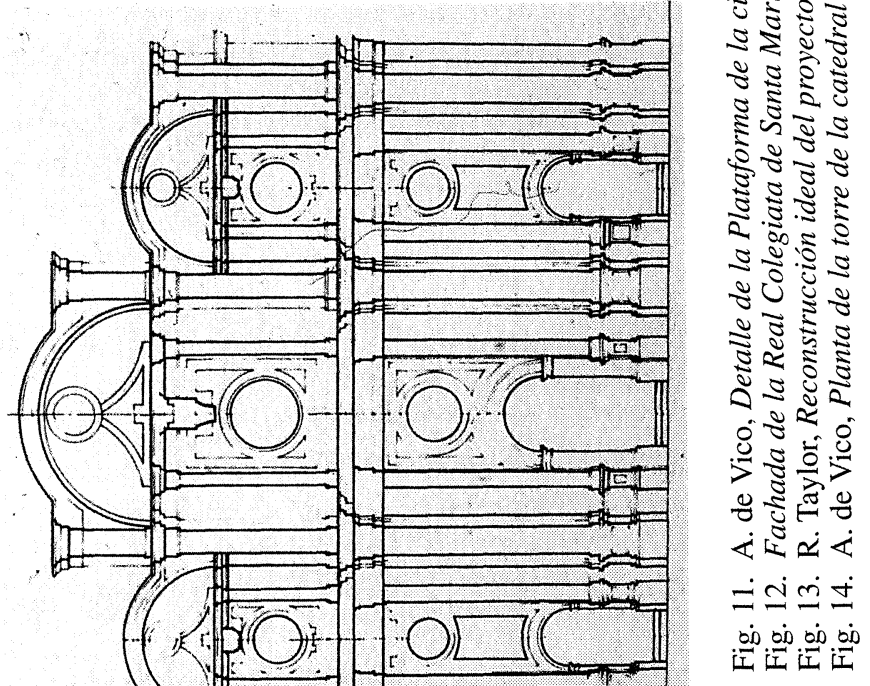

